\title{
EVOLUTION IN THE INTELLECTUAL STRUCTURE OF BIM RESEARCH: A BIBLIOMETRIC ANALYSIS
}

\author{
Timothy O. OLAWUMI ${ }^{\mathrm{a}}$, Daniel W. M. CHAN ${ }^{\mathrm{a}}$, Johnny K. W. WONG \\ ${ }^{a}$ Department of Building and Real Estate, Faculty of Construction and Environment, \\ The Hong Kong Polytechnic University, Hung Hom, Kowloon, Hong Kong \\ ${ }^{b}$ School of Built Environment, Faculty of Design, Architecture and Building, \\ University of Technology Sydney, Sydney, Australia
}

Received 29 March 2017; accepted 02 Aug 2017

\begin{abstract}
Building Information Modelling (BIM) processes have continued to gain relevance in the Architectural, Engineering, and Construction (AEC) industry with more resources directed toward it. This study conducts a bibliometric analysis of 445 BIM articles to investigate and understand the pattern of BIM research which include defining BIM research categories, evaluating the project sectors that are influenced by BIM, and tracking the funding structure of BIM research. A network map that displays a visualization of the structure of BIM literature by research origin, funding structure and geographical scope was designed. None of the previous reviews of literature analyzed the BIM articles' corpus to such level and depth. The findings revealed research categories such as construction and project management and BIM learning, adoption \& practice as the core research areas in BIM and highlighted trending research themes in BIM research. Authors based in Asia and Europe received more research grants than their counterparts in other regions; likewise, two-third of the articles was authored by academics in the United States, Korea, and the United Kingdom. The study provides its readers with relevant research areas that require considerations, and the discussion of selected research areas provides an extensive understanding of salient BIM fields.
\end{abstract}

Keywords: Building Information Modelling (BIM), bibliometric analysis, funding structure, project sectors, research areas, BIM software.

\section{Introduction}

Building Information Modelling (BIM) is currently receiving worldwide recognition in the AEC industry due to its ability to store and also ease the use and reuse of project data across the project development phases; while also preventing unnecessary replication of project or design tasks (Kovacic et al. 2015; Kim et al. 2013; Lee, Yu 2016; Sun, Wang 2015). However, BIM is a revolving and innovative digital technology (Mahalingam et al. 2015; Malekitabar et al. 2016; Succar, Kassem 2015); with recent applications in areas such as sustainability (Ajayi et al. 2015; Liu et al. 2015a) and facility management (Motamedi et al. 2013); despite the fragmented nature of the construction industry.

Meanwhile, BIM has started to receive more attention in the academic community with several research papers on BIM. It include articles on the development of BIM curriculum for university undergraduate students. Related works on BIM curriculum development including literature such as "course development and collaborative teaching" (see Ahn et al. 2013; Becerik-Gerber, Kensek 2010; Becerik-Gerber et al. 2012a; Kim 2012; Sacks,
Barak 2010; Wang, Leite 2014; Wu, Issa 2014). It also includes "evaluating BIM curriculum vis-à-vis industrial needs" (Aibinu, Venkatesh 2014; Solnosky et al. 2014) and "in-class experimentation with BIM tools" (Lewis et al. 2015; Nassar 2012) among many other related topics.

BIM per Eastman et al. (2008) is "a new approach to design, construction, and facilities management, in which a digital representation of the building process [is used] to facilitate the exchange and interoperability of information in digital format". Gilkinson et al. (2015) regarded it as both constituting a process and technology. It is an innovative solution with much to be explored; they further stressed that since it ensured a "coordinated integrated process"; it is a useful tool for all project stakeholders as they could found it fit and suitable for their jobs due to its diverse nature (Olawumi, Ayegun 2016), and the collaborative outlook of the construction industry (Olatunji et al. 2016a, 2016b), despite the increasing complexity of construction projects (Olatunji et al. 2017a). Olatunji et al. (2017b) listed one of the benefits of BIM as an increase 
in return on investment (ROI) for clients; and to "facilitate the ease of dissemination of information" and this, in turn, helps to secure project success (Olawumi 2016; Olawumi et al. 2016). Also, related technological tools such as augmented reality (AR) system and Geographic Information System (GIS) have also been integrated into the BIM process to facilitate the visualization of the construction process.

\section{Knowledge gap and research objectives and value}

Previous studies on reviews of BIM literature have focused on specific research areas or themes such as facility management (Becerik-Gerber et al.2012b; Kang, Hong 2015; Wetzel, Thabet 2015), environmental sustainability (Wong, Zhou 2015). Studies have outlined the current practices and future directions via various research approaches such as surveys, critical literature reviews, and interviews (Azhar 2011; Gu, London 2010; Volk et al. 2014). More so, researchers have carried out reviews and analyses on BIM which include contractors' blueprint to adopt BIM (Ahn et al. 2016); e-tendering process model (Ajam et al. 2010); waste management (Ajayi et al. 2015; Akinade et al. 2015); education and knowledge (Ahn et al. 2013; Alci, Sampaio 2015). Others include: social network simulation, cloud-BIM and technology adoptions (Al Hattab et al. 2015; Alreshidi et al. 2016; Arayici et al. 2011; Becerik-Gerber et al. 2012a; BecerikGerber, Kensek 2010; Chen, Hou 2014; Choi, Kim 2015; Davies, Harty 2013; Du et al. 2014).

Extant studies also exist on BIM-GIS integration (Bansal 2011; Borrmann et al. 2015; Deng et al. 2016) and sustainability (Bynum et al. 2013; Henry et al. 2015; Inyim et al. 2015). However, in recent years (2015-2017) there have been literature reviews (see Table 1 and Table 2) on BIM research field such as Yalcinkaya and Singh (2015), who reviewed BIM literature to deduce twelve (12) BIM core research areas and ninety (90) factor labels using Latent Semantic Analysis (LSA) described as a "natural language processing technique"; which was used to analyze the abstracts of the journal articles. Meanwhile, Zhao (2017) used a computer software "Citespace" to examine citation records downloaded from the Web of Science database to identify authors with the most citations and co-citations and the "hot topics" in BIM research areas with the most citations. More so, Santos et al. (2017) review of the extant literature focused on identifying research areas with the most citations and the most cited authors. Accordingly, he also proposed nine (9) research areas in BIM field. Table 1 and Table 2 identifies and summarize what is new in this current study and compares it with previous published reviews of BIM literature.

Moreover, previous BIM reviews focused mostly on authors and journals' citations analyses, this study attempts to bridge the gap in the reviews of extant literature and add value to BIM knowledge area. This study proposes the following objectives: (1) to carry out an holistic review of BIM journal articles (as against abstracts' review by Yalcinkaya and Singh (2015) and citations records by Zhao (2017)); (2) to define the subfields that constitute the intellectual structure of BIM research fields (core research categories and areas); (3) to identify funding (grants) structure for BIM research based on country (research origin) analysis and research category analysis; (4) to identify and establish the network of BIM publication by research origin and geographical scope; (5) to identify the salient research methodology employed in past BIM studies; (6) to identify relevant BIM software, data schema, and project areas for BIM application; and (7) to classify BIM publications based on project sectors they are applied to (such as energy, transportation, etc.).

Meanwhile, throughout the bibliometric analysis and the literature reviews, the study would adopt a more systematical and analytical approach in achieving the seven (7) objectives of this study. A wide range of publication will be analyzed across several journal publication houses. The next section focuses on a discussion of the research methodology applied (bibliometric analysis) and the literature search strategy. Other sections focus on (i) the findings and discussion of the results of the bibliometric analysis; (ii) discussion on the proposed core BIM research categories and areas; (iii) the research implications; (iv) research limitations; and (v) the conclusion and future directions.

\section{Research methodology}

The study adopted a bibliometric analysis technique to achieve the predefined research objectives of which is to articulate the distinct set of the main research categories in BIM's research to gain a better perspective and identify critical areas in which more research efforts is still been required. Per Marsilio et al. (2011) bibliometric research approach is an "attempt(s) to quantify and address the intellectual structure of a research field starting from the mathematical and statistical analysis of patterns that appear in the publication and use of documents". Meanwhile, this analysis technique has been utilized in some research publications both in the science and management research fields (see Neto et al. 2016; Marsilio et al. 2011; Ramos-Rodríguez, Ruíz-Navarro 2004).

This research aims to bridge the gap in the BIM literature by applying the bibliometric technique to a corpus of published articles relevant to this disciplinary field towards achieving the predefined objectives as stated in the previous section. The research design for this study is as outlined in Figure 1.

\subsection{Literature search strategy}

In commencing the bibliometric analysis, a decision as to which scientific repository to use was made; there are several academic digital databases, but the three most commonly utilized for scientific inquiries include Google Scholar, ISI Web of Science and Scopus. Although there is no clear difference in Scopus and Web of Science databases as it pertains to science-based 


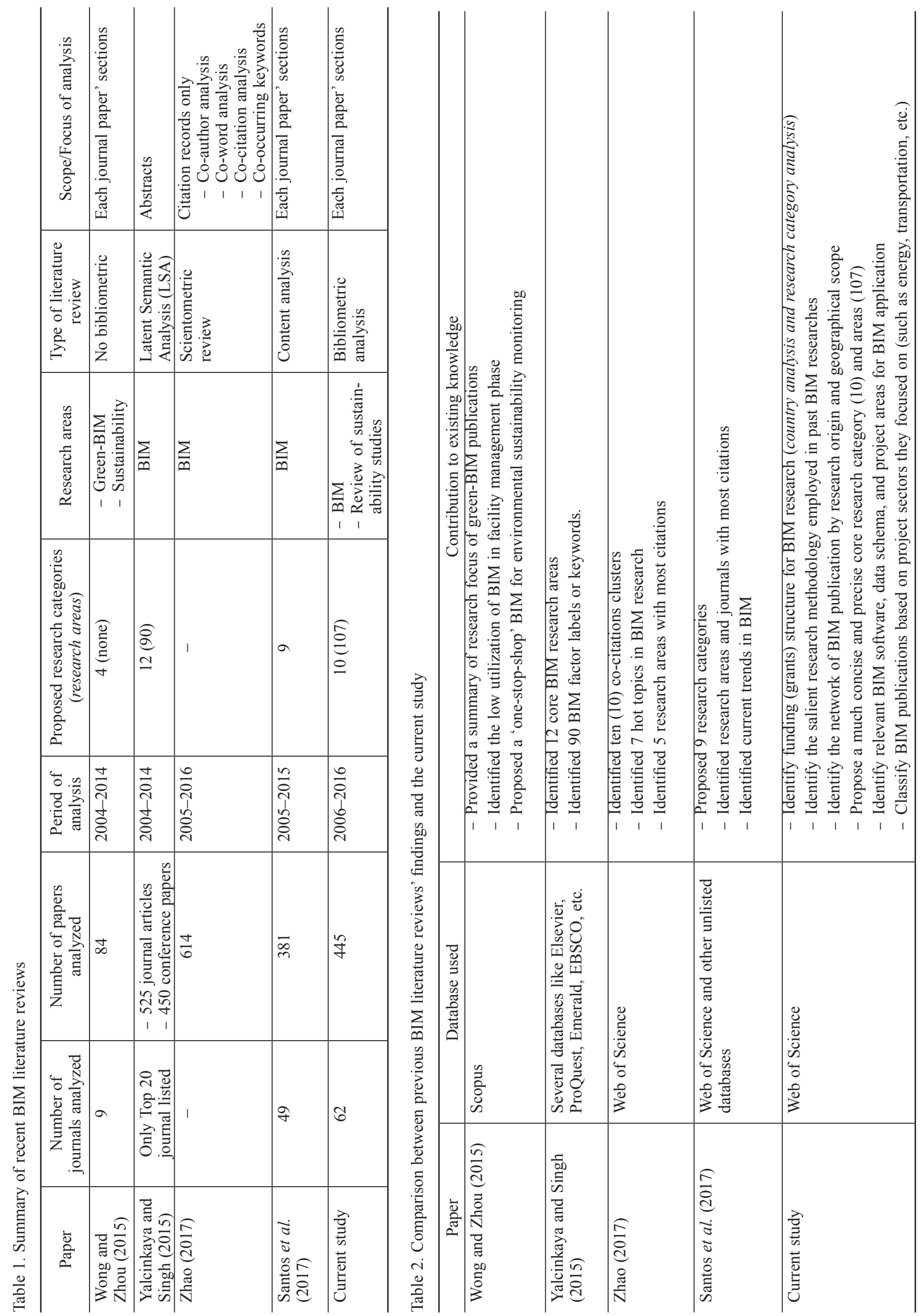




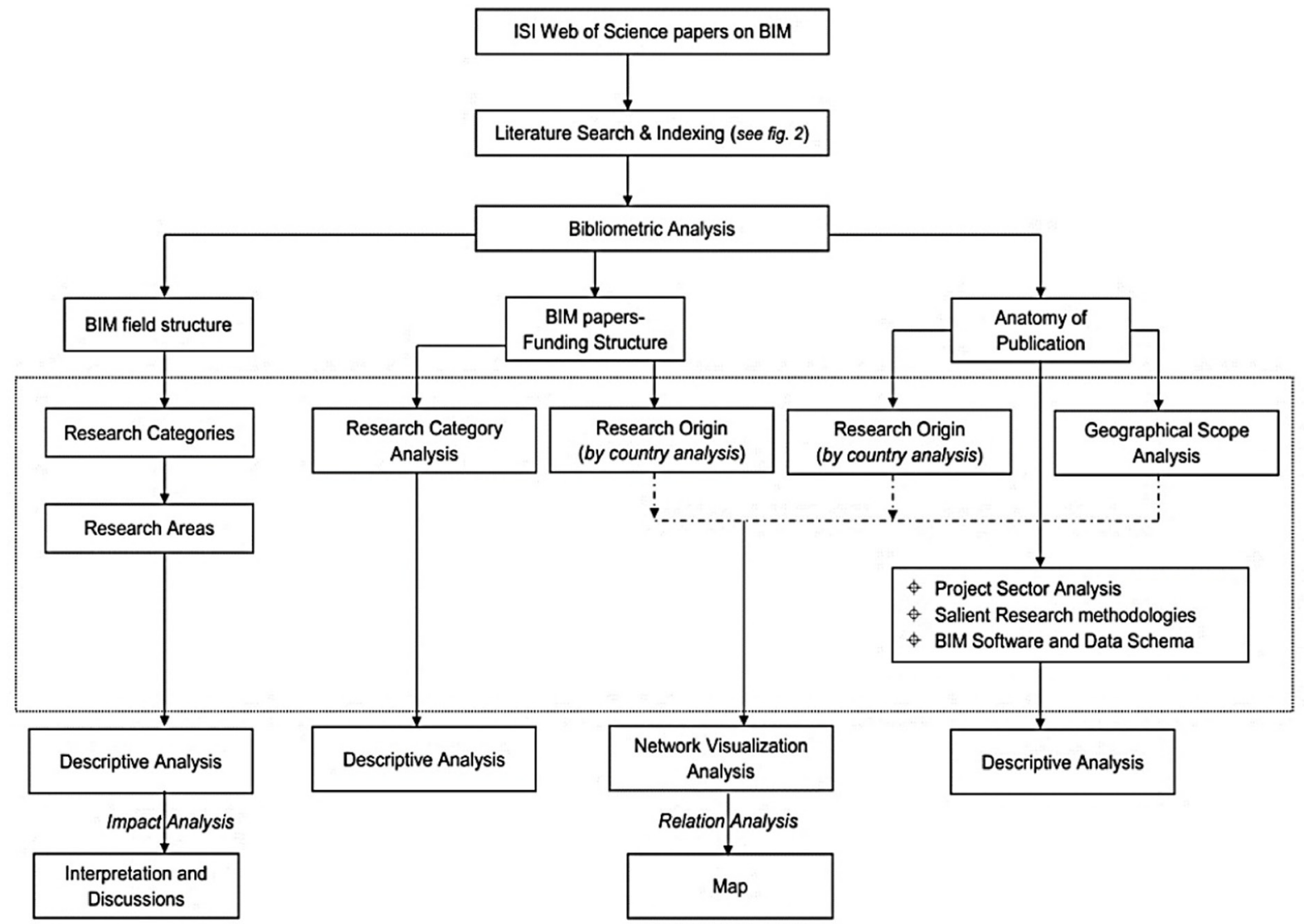

Fig. 1. Outline of research design

publications, however, there is a considerable overlap in their records. Moreover, Google Scholar seems to have a more extensive collection of publications than both Scopus and Web of Science. However, Google Scholar is noted to contain many incorrect publication attributions, as an author with the same first initial and last name may be attributed more citations. Also, Google Scholar also has another minor problem with indexing of articles, as it counts all conference abstracts which has nothing to do with citations, thereby increasing the numbers of papers very dramatically.

However, for this study, a comprehensive search as detailed in Figure 2 was carried using the ISI Web of Science database because of its "comprehensiveness, organized structure and scientific robustness" (Neto et al. 2016). Marsilio et al. (2011) also argued that it is the "most commonly used and generally accepted source for bibliometric studies". The search keywords are: "Building Information Modelling", "BIM" and "Building Information Modeling".

The selected time span is between 1990 and 2016 equivalent to 26 years. The research corpus only comprises of articles published in a journal instead of a doctoral thesis (since most of them are afterward published in journals), books or conference papers. Moreover, authors do publish their work in scholarly journals because they are classified as "certified knowledge"
(Ramos-Rodríguez, Ruíz-Navarro 2004) and have gone through a peer-review process. The search results gave 567 journal articles. However, 122 papers were excluded from further analysis as they fail to meet the inclusion criteria (see Table 3) due to several reasons such as abstracts written in a language other than English (12 articles). We also have three articles with no abstracts and 107 articles found to be unrelated to research (such as

Table 3. Indexed corpus profile

\begin{tabular}{|c|c|c|}
\hline Profile & $\begin{array}{l}\text { Number } \\
\text { of papers }\end{array}$ & $\begin{array}{l}\text { Percentage } \\
\quad(\%)\end{array}$ \\
\hline $\begin{array}{l}\text { Total publications in web of } \\
\text { science }\end{array}$ & 567 & 100 \\
\hline $\begin{array}{l}\text { Abstracts which are written in } \\
\text { languages other than English }\end{array}$ & 12 & 2.12 \\
\hline $\begin{array}{l}\text { Papers excluded for not having } \\
\text { abstracts }\end{array}$ & 3 & 0.53 \\
\hline $\begin{array}{l}\text { Papers excluded for being } \\
\text { registered twice }\end{array}$ & 0 & 0 \\
\hline $\begin{array}{l}\text { Papers excluded for not being } \\
\text { related to the } \\
\text { research area/topic }\end{array}$ & 107 & 18.87 \\
\hline $\begin{array}{l}\text { Total papers excluded before } \\
\text { analysis }\end{array}$ & 122 & 21.52 \\
\hline $\begin{array}{l}\text { Total papers to be analyzed for } \\
\text { this guided study research }\end{array}$ & 445 & 78.48 \\
\hline
\end{tabular}




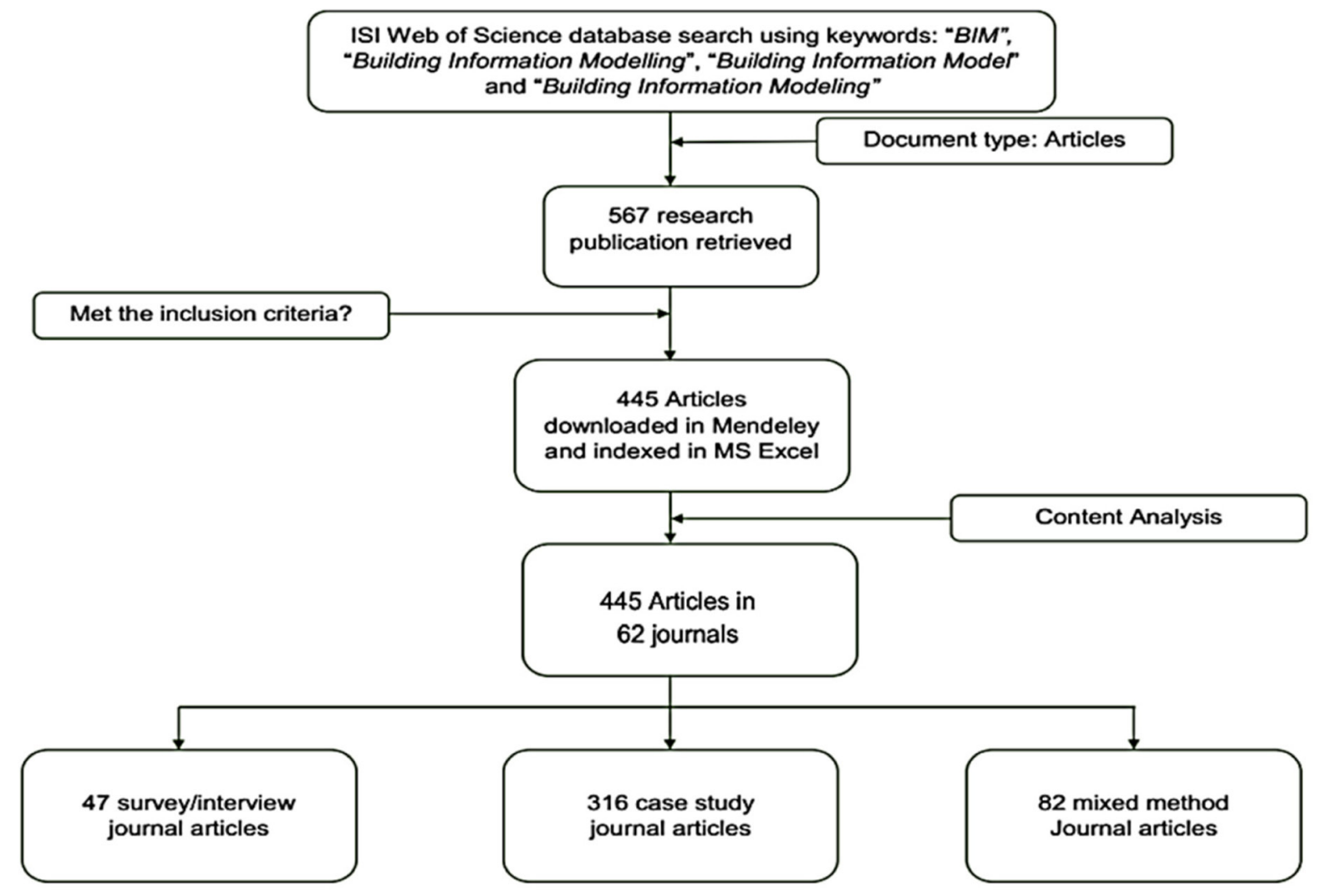

Fig. 2. Literature search and indexing approach

papers that only refer to BIM but cannot be related to any of the categorized research areas). A total 445 articles which were downloaded in Mendeley Desktop (reference manager) and indexed in the Microsoft Excel program. The indexed articles consisted of 316 case studies papers, 47 surveys/interviews articles, and 82 articles which utilized mixed method research approach.

\section{Bibliometric analysis}

This section discusses the facets and results of this study of bibliometric analysis. These include (i) descriptive analysis of published research in BIM; (ii) defining the BIM subfields and research areas; (iii) BIM funding structure; and (iv) the anatomy of the BIM publications as outlined in this study research design.

\subsection{Published research in BIM}

The volume of published research in BIM has notably increased in recent years (Santos et al. 2017); since it has emerged as a key, and innovative approach to construction and civil engineering (Yalcinkaya, Singh 2015) and these studies covers diverse areas including several technical and non-technical issues (Zhao 2017). More so, in the last four years, more than 75 percent of BIM articles were published.

The literature used in this bibliometric analysis are journal articles, and all but one of the journal has no im- pact factor (IF). The analysis of the journals reveals that 36 out of the 62 journals ( 58 per cent) has an impact factor (IF) greater than 1.000 while 16 journals have IF value between 0.500 and 0.999 representing 26 per cent and the rest of 9 journals are below 0.500 IF value. Meanwhile, an analysis of BIM publishing journals reveals several concepts and issues revolving around the BIM research field; also 32 out of the 62 journals ( 52 per cent) published just one article. More so, another cluster of 20 journals published between 2 and 6 papers; meanwhile, there is another group of ten (10) journals whose number of published articles on BIM is 10 articles or more (see Table 4).

The structure of the published research on BIM closely followed the "Pareto-principle" also known as the 80/20 rule (Brynjolfsson et al. 2011; Pareto 1964). In this study, it follows that 349 articles (78.4 percent) are published in just 10 journals (16 per cent) which can be termed a 78/16 rule which aligns with the Pareto postulation; the average impact factor for the 10 journals whose publications followed the Pareto principles is 1.568. More so, from year 2012 to date the number of published articles on BIM have significantly increased with more volumes of articles coming from journals such as "Automation in Construction", "Advanced Engineering Informatics", and "Journal of Computing in Civil Engineering". 


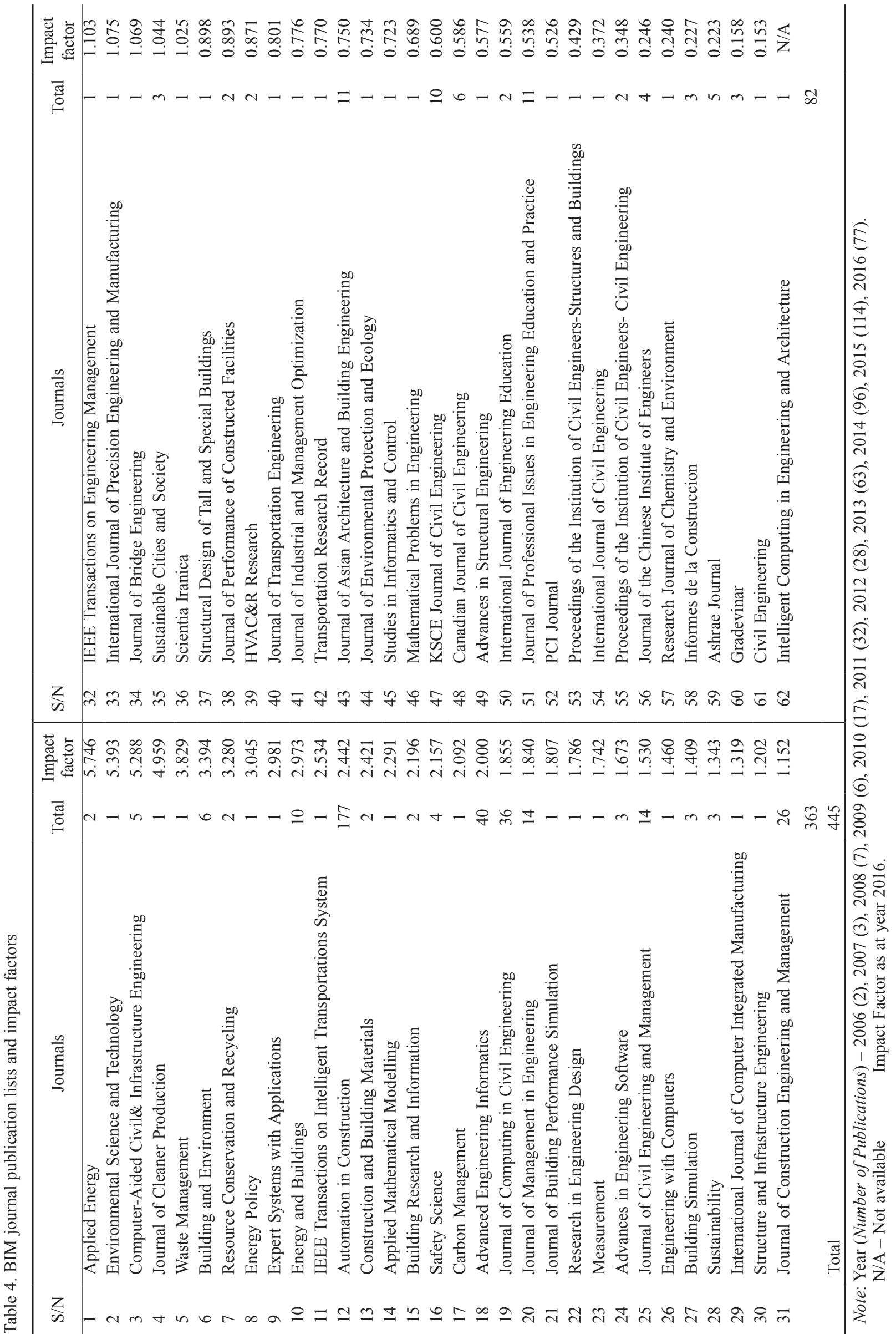




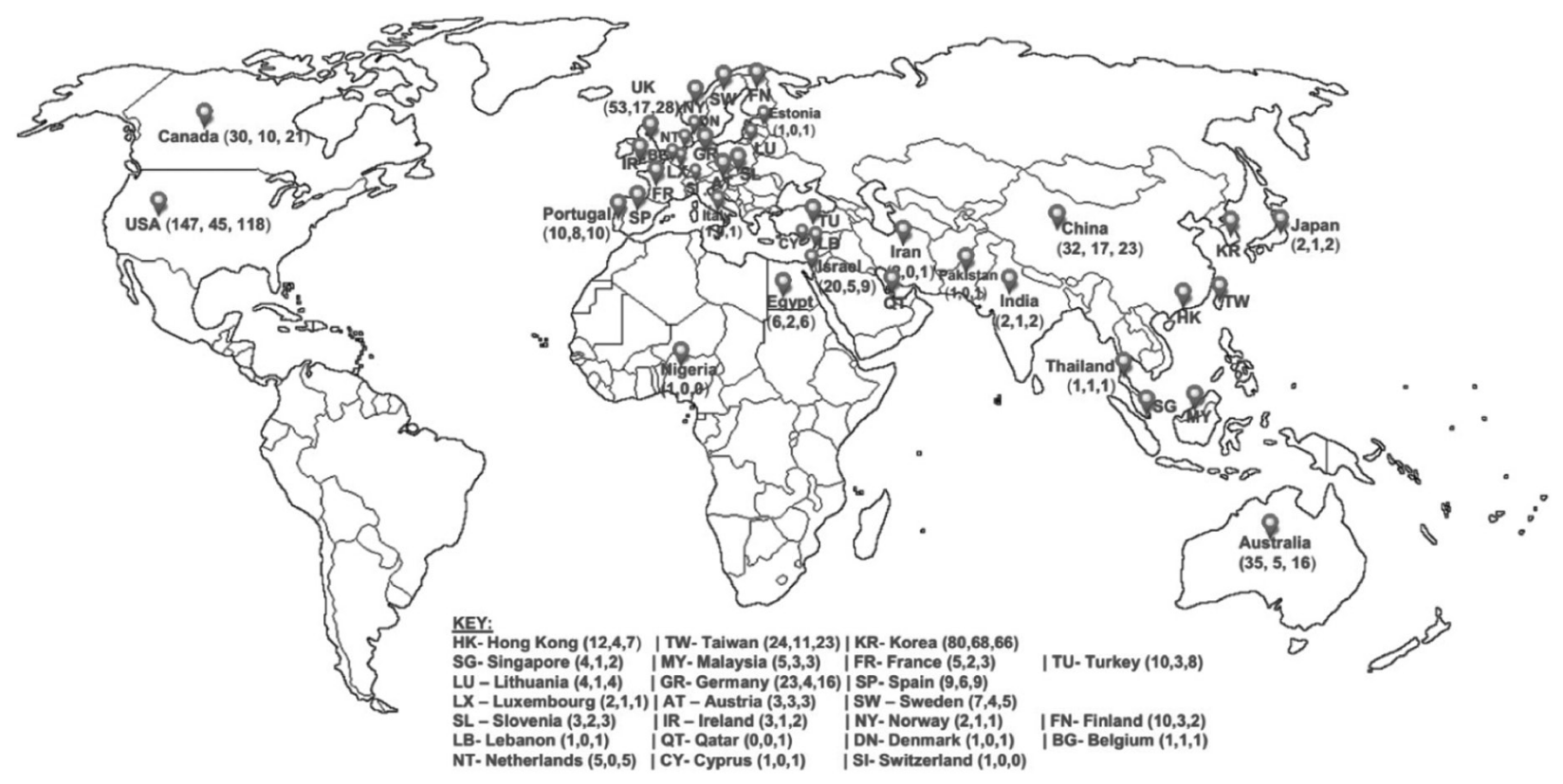

Fig. 3. Map network visualization analysis (funding structure)

\subsection{BIM sub-fields and research areas}

The next stage in the bibliometric analysis is to define the BIM sub-fields (research categories and research areas). We identify ten (10) research categories namely "IT-enabled simulations and visualization"; "building design and energy conformance"; "BIM software \& data schema"; "BIM model development"; "BIM learning, adoption \& practice"; "construction and project management"; "safety and risk management"; "facility management"; "sustainability-related studies"; and "literature review" (see Table 5).

The establishment of the semantic link and classification of the published works to the ten (10) research categories was based on a directed content analysis approach using articles keywords, titles, scope covered

Table 5. BIM research categories

\begin{tabular}{llc}
\hline Code & \multicolumn{1}{c}{ BIM- Research Categories } & $\begin{array}{c}\text { Number of } \\
\text { articles }\end{array}$ \\
\hline RC1 & $\begin{array}{l}\text { IT-enabled simulations and } \\
\text { Visualisation }\end{array}$ & 40 \\
RC2 & $\begin{array}{l}\text { Building design and Energy } \\
\text { conformance }\end{array}$ & 65 \\
RC3 & BIM Software \& Data schema & 54 \\
RC4 & BIM model development & 52 \\
RC5 & BIM learning, adoption \& practice & 70 \\
RC6 & Construction and Project & 78 \\
RC7 & Management & Safety / Risk Management \\
RC8 & Facility management & 31 \\
RC9 & Sustainability & 37 \\
RC10 & Literature review & 17 \\
\hline
\end{tabular}

and the research findings. Meanwhile, further clustering of the articles enables us to define one hundred and ten (107) research areas/themes based on the ten research categories. The analysis of the research categories reveals a prevalent of publication in aspects such as "construction and project management" with 78 articles; "BIM learning, adoption \& practice" with 70 articles; and "building design and energy conformance" with 65 articles which sums up close to fifty (50) percent of all published works in BIM. The defined category in this study is more concise and specific than previous studies, although there is a partial overlap when compared with those provided by previous authors (Yalcinkaya, Singh 2015; Zhao 2017).

Furthermore, for the research areas, one hundred and ten (107) themes were identified (see Table 6) through an iterative process whereby identified themes are grouped in a cluster under each research category. After the loading of the research themes into the research categories, three research areas - "construction and project management" with 18 themes, "facility management" with 17 themes and "BIM model development" with 16 themes are the most represented research areas. It can be deduced from the analysis that BIM has found more application in research in construction and project management with more published articles and themes, this is because of diverse use in the construction industry (Zhao 2017); and the fact that more contractor has started making use of BIM (Fan et al. 2014). Further discussion on the research categories and areas are outlined in Section 4 of this study.

\subsection{BIM publications' funding structure}

BIM disciplinary field is a technologically backed research area which requires researchers to experiment 
Table 6. Theme loading for the BIM research areas

\begin{tabular}{|c|c|c|}
\hline $\begin{array}{l}\text { Code } \\
\text { (research } \\
\text { category) }\end{array}$ & Research areas/themes & $\begin{array}{l}\text { Number } \\
\text { of themes }\end{array}$ \\
\hline $\mathrm{RC} 1$ & $\begin{array}{l}\text { RC1.1 - Emergencies sensing localization RC1.2 - Real-time and 3D visualizations } \\
\text { RC1.3 - Fire safety simulations RC1.4 - Point-cloud data extraction } \\
\text { RC1.4 - Automated or semi-automated generation of data } \\
\text { RC1.5 - Virtual support systems RC1.6 - Synchronous online collaboration. }\end{array}$ & 6 \\
\hline $\mathrm{RC} 2$ & $\begin{array}{l}\text { RC2.1 - Building energy regulations RC2.2 - Code checking \& compliance } \\
\text { RC2.3 - Building envelope cost and energy performance RC2.4 - Energy management and analysis } \\
\text { RC2.5 - Structural analysis and design RC2.6 - Building rating systems and assessments } \\
\text { RC2.7 - Tracking of design changes and errors RC2.8 - Daylighting profiling } \\
\text { RC2.9 - Design validation and coordination. }\end{array}$ & 9 \\
\hline $\mathrm{RC} 3$ & $\begin{array}{l}\text { RC3.1 - Interoperability RC3.2 - Usefulness, benefits, and limitations of BIM applications } \\
\text { RC3.3 - Augmented reality system RC3.4 - Industry Foundation Class (IFC) } \\
\text { RC3.5 - BIM \& Semantic web interoperability RC3.6 - Semiotic User interface analysis } \\
\text { RC3.7 - Cost Estimating BIM tools RC3.8 - Software coupling RC3.9 - BIM data exchanges } \\
\text { RC3.10 - Mobile BIM RC3.11 - Data schemas (GbXML, City GML, MVD, etc.). }\end{array}$ & 11 \\
\hline $\mathrm{RC} 4$ & 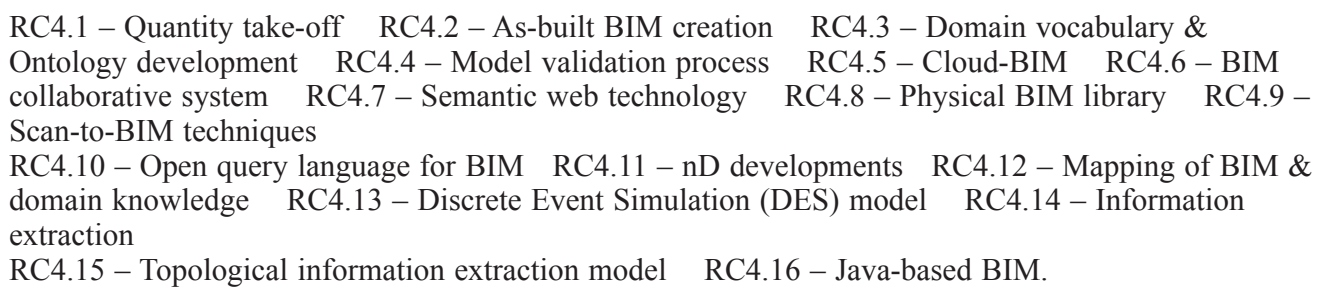 & 16 \\
\hline $\mathrm{RC} 5$ & $\begin{array}{l}\text { RC5.1 - BIM usage and adoption RC5.2 - BIM curriculum development } \\
\text { RC5.3 - Construction stakeholders' BIM adoption strategies RC5.4 - BIM teaching and support } \\
\text { RC5.5 - Drivers of BIM adoption RC5.6 - Cost-benefit analysis of BIM implementations } \\
\text { RC5.7 - BIM adoption barriers RC5.8 - BIM standardization \& Intellectual property rights } \\
\text { RC5.9 - BIM competency assessment RC5.10 - BIM ethics \& professionalism } \\
\text { RC5.11 - BIM practice paradigms \& governance approach. }\end{array}$ & 11 \\
\hline RC6 & 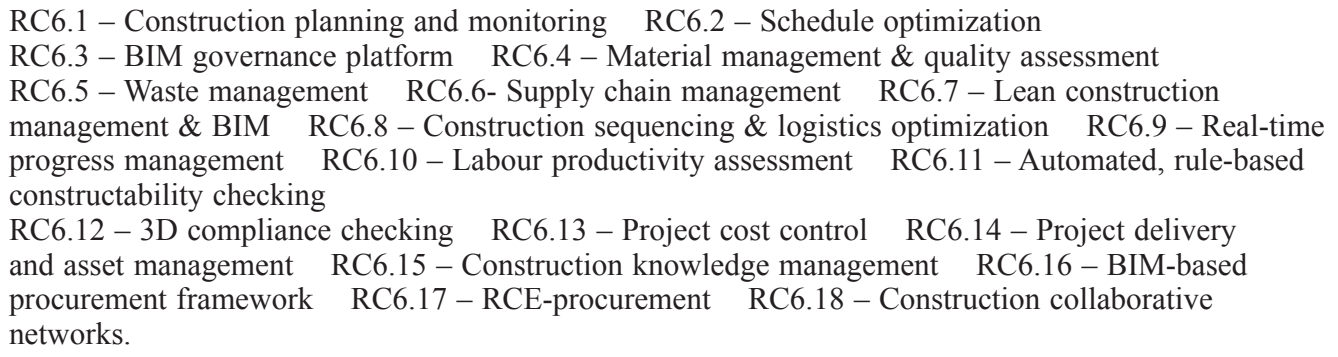 & 18 \\
\hline $\mathrm{RC7}$ & $\begin{array}{l}\text { RC7.1 - Automated safety planning and management RC7.2 - Risk knowledge management } \\
\text { RC7.3 - Walkability \& hazardous area identification RC7.4 - Site risk identification } \\
\text { RC7.5 - Search \& Rescue algorithm RC7.6 - Fire safety management } \\
\text { RC7.7 - Workspace safety and requirements RC7.8 - Automatic safety checking of construction } \\
\text { models. }\end{array}$ & 8 \\
\hline $\mathrm{RC} 8$ & 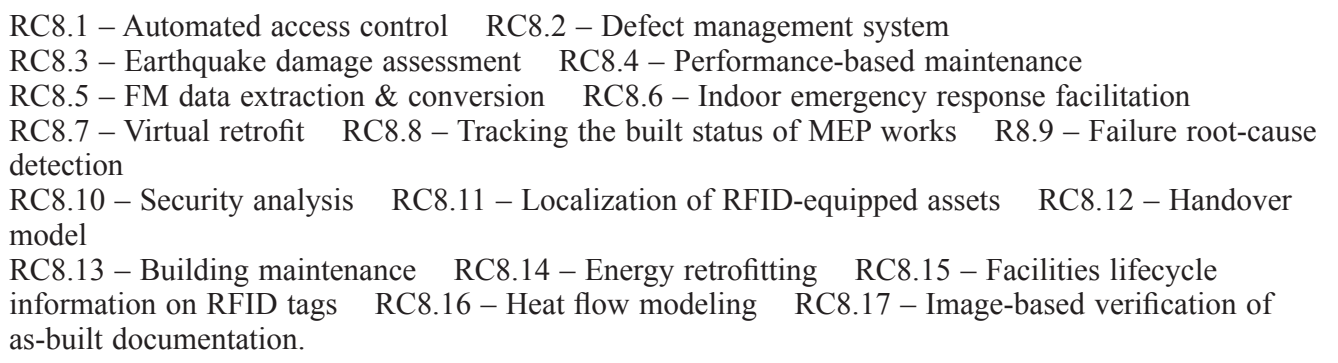 & 17 \\
\hline RC9 & $\begin{array}{l}\text { RC9.1 - Sustainability performance of building } \text { RC9.2 - Environmental impact evaluation } \\
\text { RC9.3 - Integrating BIM \& LEED RC9.4 - Sustainable energy usage } \\
\text { RC9.5 - BIM-based decision support for master planning RC9.6 - Sustainability Appraisal (steel } \\
\text { design) } \\
\begin{array}{ll}\text { RC9.7 - Indoor environmental quality (IEQ) } & \text { RC9.8 - Sustainable design and construction } \\
\text { RC9.9 - 3D analysis of lifecycle assessment } & \text { RC9.10 - Sustainable material selection. }\end{array}\end{array}$ & 10 \\
\hline $\mathrm{RC} 10$ & RC10.1 - Pattern and trend in BIM research. & 1 \\
\hline
\end{tabular}


with, develop and interoperate various BIM software and tools of which many of them are only commercially available and expensive, hence this section attempts to investigate the funding arrangement used in the various journal articles.

The bibliometric analysis in this section focuses on reviewing the funding structure (i) based on research category analysis, and (ii) research origin analysis (author \& co-authors' affiliations). An analysis of the funding structure reveals a steady increase in the number of BIM research receiving some form of funding or grants to carry out the relevant studies (from 20 articles in 2011 to 67 articles in 2015); also, more than half (51 percent, \#231 articles) received funding. Meanwhile, based on an analysis of the research categories which received more funding, we identified four (4) research categories which have more than thirty (30) funded articles, and these include: RC2 - "Building design and Energy conformance" which 40 funded articles, RC6 - "Construction and Project Management". Others are RC3 - "BIM Software \& Data schema", and RC4 - "BIM model development" with 39,35 and 32 funded articles respectively which represent more than 60 percent of the funded articles of all BIM research categories (see Table 7).

More so, the analysis of the funding structure of BIM publication (based on research origin analysis) was analyzed using a mapped network visualization technique as shown in Figure 3. The funding arrangement for any given article was based on the information provided by the author(s) in the acknowledgment section of the published paper. The format for the map network visualization analysis in Figure 3 is based on "Country" ("articles per research origin", "funded articles", "articles per geographical scope"). Therefore, by "articles per research origin" we imply the number of articles published by the author(s) or co-author(s) affiliated with an institution based in that country. More so, the term "articles per geographical scope" implies the number of articles with originating data or case studies based in that country. A

Table 7. Funding structure

\begin{tabular}{ccc|ccc}
\hline Year & $\begin{array}{c}\text { Funded } \\
\text { articles }\end{array}$ & $\begin{array}{c}\text { Percent } \\
(\%)\end{array}$ & $\begin{array}{c}\text { Research } \\
\text { categories }\end{array}$ & $\begin{array}{c}\text { Funded } \\
\text { articles }\end{array}$ & $\begin{array}{c}\text { Percent } \\
(\%)\end{array}$ \\
\hline 2016 & 40 & 17.3 & RC1 & 21 & 9.1 \\
2015 & 67 & 29 & RC2 & 40 & 17.3 \\
2014 & 46 & 19.9 & RC3 & 35 & 15.2 \\
2013 & 32 & 13.9 & RC4 & 32 & 13.9 \\
2012 & 10 & 4.3 & RC5 & 26 & 11.3 \\
2011 & 20 & 8.7 & RC6 & 39 & 16.9 \\
2010 & 8 & 3.5 & RC7 & 15 & 6.5 \\
2009 & 5 & 2.2 & RC8 & 16 & 6.9 \\
2008 & 1 & 0.4 & RC9 & 7 & 3 \\
2007 & 2 & 0.9 & RC10 & 0 & 0 \\
2006 & 0 & 0 & & & \\
Total & 231 & 100 & & 231 & 100 \\
\hline
\end{tabular}

bibliometric analysis of public-private partnership (PPP) by Neto et al. (2016) also used the terms "research origin" and "geographical scope" to portray similar expressions.

For example, we have USA $(147,45,118)$ - this imply that they are 147 BIM authors/co-author(s) from the United States based on the bibliometric analysis and 45 of their BIM articles were funded, while there are 118 articles with the research data (that is, case studies, questionnaire surveys or interviews, etc.) based solely in the United States. BIM articles from countries namely the Republic of Korea, the US and China, have more funded articles with 68,45 and 17 articles than any other countries which represent a combined 56 percent of all funded articles. The funding of BIM projects in South Korea, and China has aided the adoption and implementation of BIM in the AEC industries of these two countries; also, BIM standards, guidelines and component families which are essential for successful BIM implementation have been developed in Korea (G-SEED) and Hong Kong (BEAMPlus).

The relative high funding rate from the Republic of Korea is not far-fetched because as noted by Lee and Yu (2016), the Korean central government have strongly encouraged BIM usage and adoption via the promulgation of policies and funding through the National Research Foundation of Korea (NRF). Also, a recent study by Won et al. (2013) revealed a significant increase in the adoption rate in both USA and Korea.

\subsection{Anatomy of BIM publications}

This section focuses on other aspects of the anatomy of the published BIM articles as depicted in the research design. The bibliometric analysis in this section focuses on (i) project sector analysis; (ii) the salient research methodologies; (iii) related BIM software and data schema.

\subsubsection{Project sector analysis}

A bibliometric analysis of the corpus of BIM publications reveal a greater focus on the 'building and housing sector' of the built environment with a total of 347 BIM articles out of the overall 445 articles. BIM articles in the "building and housing" sector focuses on aspects such as "single family houses", "residential floors", "parking garage", "storey buildings", "high-rise structures", "building component and elements", "sports centers", and "educational buildings" (see Table 8). A study by Chang and Lin (2016) reveals that BIM "is currently being applied mostly to buildings" with few applications elsewhere. Table 8 outlines the project sectors covered by the BIM publication corpus as deduced through this study's bibliometric analysis; meanwhile, aspects covered by the articles under each project sectors were defined.

\subsubsection{Salient research methodologies}

The bibliometric analysis of the articles' corpus in this section focus on defining the primary research design and 
Table 8. Articles' project sector analysis

\begin{tabular}{|c|c|c|}
\hline Project Sector & Aspects covered & $\begin{array}{l}\text { Number of } \\
\text { articles }\end{array}$ \\
\hline $\begin{array}{l}\text { Building and } \\
\text { Housing }\end{array}$ & $\begin{array}{l}\text { Single family houses; Residential floors; Parking garage; Storeys buildings; High-rise } \\
\text { structures; Building component and elements, Sports center, Educational buildings }\end{array}$ & 347 \\
\hline Transportation & $\begin{array}{l}\text { Bridges; Highways; Tunnel construction; Subways; Airports; Subway stations; Railways; } \\
\text { Railway tracks }\end{array}$ & 17 \\
\hline Environment & $\begin{array}{l}\text { Safe walking environment; Safety; Traffic noise control; Earthquake damage assessment; } \\
\text { Waste effectiveness; Hazard identification \& prevention; Safety planning; Work-Space } \\
\text { Planning }\end{array}$ & 24 \\
\hline Education & $\begin{array}{l}\text { BIM curriculum development; BIM implementation; BIM in Quantity Surveying practice; } \\
\text { BIM teaching; Developing Students' Collaborative Skills; Course developments }\end{array}$ & 22 \\
\hline $\begin{array}{l}\text { Energy } \\
\text { infrastructure }\end{array}$ & Natural gas plant construction; Gas pipeline; Renewable energy system & 5 \\
\hline General & $\begin{array}{l}\text { Applies to all project sectors (Procurement, Estimating, Construction projects \& Built } \\
\text { environment) }\end{array}$ & 28 \\
\hline $\begin{array}{l}\text { Urban } \\
\text { regeneration }\end{array}$ & Post-earthquake operations (such as search and rescue, and damage assessment) & 2 \\
\hline
\end{tabular}

Table 9. BIM software and data schema

\begin{tabular}{|c|c|c|}
\hline BIM software category & Software (frequency of mentions or usage) & Number \\
\hline Data Schema & $\begin{array}{l}\text { Industry Foundation Classes [IFC] - 187; GbXML [green building XML] }-30 \\
\text { MVD [model view definitions] - 22; IFCXML }-22 ; \text { AecXML }-5 ; \text { City GML }-4 ; \\
\text { Omni class }-2 ; \text { NBDM [TrySys] }-1 ; \text { bcXML }-1 ; \text { LandXML }-1 ; \text { EcoXML }-1\end{array}$ & 11 \\
\hline $\begin{array}{l}\text { Architectural and Structural } \\
\text { tools }\end{array}$ & $\begin{array}{l}\text { Autodesk Revit }-132 \text {; Graphic Soft ArchiCAD - 67; AutoCAD - 28; Bentley } \\
\text { Architecture systems - 26; Vico Constructor }-13 \text {; Digital Projects }-8 \text {; } \\
\text { Nemetschek AllPlan }-8 \text {; Nemetschek Vectorworks }-4 \text { Google SketchUp }-3 \text {; } \\
\text { Autodesk Inventor }-1\end{array}$ & 10 \\
\hline $\begin{array}{l}\text { Building Energy Analysis \& } \\
\text { Simulation Tools }\end{array}$ & $\begin{array}{l}\text { Energy Plus - 24; Ecotect - 17; IES VE - 10; eQuest - 10; DOE-2.2 - 7; } \\
\text { Radiance - } 6\end{array}$ & 6 \\
\hline Estimating Tools & $\begin{array}{l}\text { Quantity take-off }-3 \text {; On-screen take-off }-2 \text {; Innovaya }-2 \text {; BuildSoft } \\
\text { Estimating software }-1 \text {; CATO CAD }-1 \text {; Estimator }-1\end{array}$ & 6 \\
\hline Structural Tools* & $\begin{array}{l}\text { Tekla structures }-30 \text {; SAP }-2 \text {; MIDAS - 2; STAAD Pro V8i - 1; ADAPT } \\
\text { (Structural Concrete Software) }-1\end{array}$ & 5 \\
\hline Construction Management Tools & Navisworks - 27; MS Excel - 13; MS Project - 11; DProfiler - 3 & 4 \\
\hline Sustainability Analysis & Green Building Studio - 13; IES Virtual Environment - 10; Project Vasari - 1 & 3 \\
\hline Model Viewer & Solibri Model Viewer - 32; Bentley Micro Station - 13 & 2 \\
\hline Geographic Information System & ESRI's ArcGIS - 4 & 1 \\
\hline Ontology Development Tools & Protégé - 2 & 1 \\
\hline
\end{tabular}

approaches utilized by previous BIM authors. An analysis of the articles reveals that 316 articles out of 445 BIM articles (i.e. 71 percent) utilize the case study as the research method, this implies that BIM articles' authors prefer case study approaches in their studies. Basbagill et al. (2013) argued that case study research design is the best approach to introduce new concepts to industry practice and since BIM is still relatively new to the construction industry; and this can be adduced as the reasons behind the use of case studies for BIM researches.

More so, Davies and Harty (2013) believed case study research method does help to challenge funda- mental misconceptions when applying innovative technologies to practice; although, case study approach has no need for internal validation (Hartmann et al. 2012). Furthermore, the analysis of the articles' corpus shows that "questionnaire surveys and interviews" research approaches with 47 articles (11 percent) and "general discourse and literature reviews" approaches with 38 articles (8 percent) are also quite common among BIM authors.

\subsubsection{BIM software and data schema}

The bibliometric analysis of the BIM articles in this section assesses the frequency of usage and mentions of dif- 
ferent BIM software and data standard as analyzed from the BIM publications' corpus. An analysis of the articles reveals that there are eleven (11) BIM data schemas in use in the construction industry; and in fact, the industry foundation class (IFC) and the green building eXtensible markup language (gbXML) are very popular among BIM authors with 187 and 30 mentions in the articles' corpus (see Table 9). However, of the two interoperability standards, IFC is mainly employed in the AEC industry (Belsky et al. 2014; Karan, Irizarry 2015; Tashakkori et al. 2015).

More so, the high usage of the IFC schema is because of its continuous improvement so as to advance interoperability among BIM software (Kota et al. 2014), although it is not yet at a satisfactory level (Aram et al. 2013). Meanwhile, the MVD schema is only a subset of the IFC schema (Lee et al. 2013). Also, the IFCXML schema is another subset of the IFC schema that allows the IFC to be transmutable over the web (Redmond et al. 2012). Furthermore, unlike IFC, the gbXML data schema is specifically developed for energy analysis while the IFC data format is a schema developed by buildingSMART and can be used for data exchange across the building life cycle (Kim et al. 2012).

Furthermore, the analysis of BIM software for architectural and structural designs reveals 10 software in use in the AEC sector, of which Autodesk Revit with 132 articles' mentions is the most used software; previous studies unveiled similar findings (see Kim et al. 2015a, 2015b, 2015c; Wang et al. 2015). Survey results by Bynum et al. (2013) revealed that Revit is the dominant BIM authoring tool in the AEC industry with 78 percent of respondents utilizing it. However, there was low usage of BIM energy analysis software such as Ecotect, IES Virtual Environment. Nevertheless, no single BIM application can support all the process functionalities required in the AEC industry.

\section{Discussions on the BIM research categories}

This section provides a semantic link between the defined BIM research categories and research areas/themes that were established in Section 3.2 with a view to providing a more qualitative analysis of the articles in alignment with the categories descriptions. Therefore, we conducted a critical appraisal of selected articles based on their relevance to the established BIM research categories.

To conserve space, we reviewed four research categories out of the ten defined BIM research categories, which are presented in the following sub-sections. Moreover, a total of 175 articles were examined in the section.

\subsection{Construction and project management (RC6)}

The research category "construction and project management" (RC6) is the most trending BIM sub-field (with 78 articles) among the ten identified research categories, and it also has the highest number of research areas with 18 themes as seen in Tables 5 and 6 . Trending topics in this field include RC6.1 - "construction planning and monitoring" (Faghihi et al. 2016; Kim et al. 2014, 2016a); RC6.2 - "schedule optimization" (Altaf et al. 2014; Chen et al. 2013; Faghihi et al. 2014; Gelisen, Griffis 2014; Kang et al. 2016; Kim et al. 2013; Liu et al. 2015a; Moon et al. 2014; Tserng et al. 2014; Wang et al. 2014a); RC6.3 - "BIM governance platform" (Dossick, Neff 2010; Farr et al. 2014; Knight 2008); RC6.4 - "Material management \& quality assessment" (Chen, Luo 2014; Francom, El Asmar 2015; Kim et al. 2015e), and RC6.5 - "Waste management" (Akinade et al. 2015; Liu et al. 2015c; Porwal, Hewage 2012; Won et al. 2016).

More so, other research areas focus on RC6.6 "supply chain management" (Babic et al. 2010; Irizarry et al. 2013; Lu et al. 2016); RC6.7 - "lean construction management \& BIM" (Dave et al. 2016; Sacks et al. 2010a, 2010b); RC6.8 - "construction sequencing \& logistics optimization" (Han et al. 2015; Kumar, Cheng 2015; Marzouk, Abubakr 2016); RC6.9 - "real-time progress management" (Kim et al. 2013; Matthews et al. 2015); RC6.10 - "labour productivity assessment" (Lee et al. 2014; Poirier et al. 2015); and RC6.11 - "automated rule-based constructability checking" (Hu et al. 2016; Nahangi, Haas 2016).

Furthermore, other research themes under RC6 are RC6.12 - "3D compliance checking" (Jiang, Leicht 2015; Nahangi, Haas 2014); RC6.13 - "project cost control" (Turkan et al. 2013; Wang et al. 2014b); RC6.14 - "project delivery and asset management" (Choi et al. 2014; Tsai et al. 2014a); RC6.15 - "construction knowledge management" (Lin 2014; Peterson et al. 2011; Wang, Leite 2016); RC6.16 - "BIM-based procurement framework" (Goedert, Meadati 2008); RC6.17 - "RCE-procurement" (Grilo, Jardim-Goncalves 2011, 2013), and RC6.18 - "construction collaborative networks" (Abedi et al. 2016; Grilo et al. 2013; Neath et al. 2014).

Furthermore, Fan et al. (2014) carried out eight (8) case studies research to assess the effect of BIM on construction projects on aspects such as request for information (RFI), reworks, schedule compliance and change orders. The findings of the case studies reveal a marked reduction in the RFI between 50 and 90 percent, fewer or no modification(s), and compromises in the project with improved quality. More so, there was more accurate schedule compliance with shorter duration and altogether less reworks and significantly fewer change orders. Meanwhile, to facilitate real-time visualization of BIM models; Johansson et al. (2015) developed a prototype BIM viewer. Tan et al. (2017) use the genetic algorithm (GA) technique to optimize for the visualization of lift planning in offshore rigs. Other studies include BIM for infrastructural projects (Bradley et al. 2016), the development of a prototype BIM-GIS architecture to facility management practices (Kang, Hong 2015); the use of geospatial and semantic technologies for pre-construction operations (Karan, Irizarry 2015), BIM for quality 
assurance (Kim et al. 2016c); BIM for work sequencing (Kim et al. 2016b); project progress and productivity improvement (Matthews et al. 2015; Nath et al. 2015), and BIM for as-built documentation (Park, Cai 2017).

In summary, there has been a significant increase in the number of publications classified under the labeled theme "construction and project management" between 2013 and 2016, in fact, 65 out of the 78 BIM articles under this research area were published during this period. More so, of the 18 BIM research areas under RC6, we have four themes with more than 6 articles, these include RC6.2 - "schedule optimization" with 11 articles, RC6.9 - "real-time progress management", RC6.18 - "construction collaborative networks" and RC6.15 - "construction knowledge management" with 9, 6 and 6 BIM articles respectively.

The review and analysis of the BIM articles reveals the benefits of BIM in construction and project management as (1) to facilitate collaboration and coordination among construction stakeholders; (2) to optimize the construction schedule; (3) to track the progress of work on site; and (4) to serve as hub or central house for the management of construction information and processes.

\subsection{BIM learning, adoption \& practice (RC5)}

The next identified BIM research category is "BIM learning, adoption \& practice" with 70 BIM articles and under this category are 11 research area/themes as shown in Tables 5 and 6. Without the framework to aid and strengthen the implementation of innovative technology, approaches or techniques in a diverse and competitive industry like the construction industry such technology or approach may not seek the light of the day. The previous statement enforces the importance of BIM paper in this research category.

More so some of these studies and research themes covered include: RC5.1 -"BIM usage and adoption" (Eadie et al. 2013; Fortner 2008; Gilkinson et al. 2015; Kim et al. 2016d); RC5.2 - "BIM curriculum development" (Pikas et al. 2013; Sacks, Pikas 2013; Sampaio 2015; Solnosky et al. 2014; Wu, Issa 2014); RC5.3 "construction stakeholders' BIM adoption strategies" (Ahn et al. 2016; Jung, Lee 2016; Salleh, Fung 2014; Xu et al. 2014); RC5.4 - "BIM teaching and support" (Gnaur et al. 2015; Kim 2012; Kovacic et al. 2015; Sacks, Barak 2010); RC5.5 - "drivers of BIM adoption" (Mom et al. 2014; Tsai et al. 2014b); RC5.6 - "cost-benefit analysis of BIM implementations" (Giel, Issa 2013; Lu et al. 2014).

Other research themes in this research category are RC5.7 - "BIM adoption barriers" (Chien et al. 2014; Watson 2011); RC5.8 - "BIM standardization \& intellectual property rights" (Fan 2014; Howard, Björk 2008; Kraatz, Hampson 2013); RC5.9 - "BIM competency assessment" (Giel, Issa 2016; Succar et al. 2013; Wong et al. 2014, 2015); RC5.10 - "BIM ethics \& professionalism" (Jaradat et al. 2013; Love et al. 2015; Succar 2009); and RC5.11 "BIM practice paradigms \& governance approach" (Al- reshidi et al. 2016; Becerik-Gerber, Kensek 2010; Hanna et al. 2013, 2014; Rezgui et al. 2013; Samuelson, Björk 2016; Taylor, Bernstein 2009; Won, Lee 2016).

A study by Lee and Yu (2016) compared the acceptance level of BIM in South Korea and the United States of which the data were collected using interviews and questionnaire surveys. Their findings revealed a higher adoption and user satisfaction rate in the US than those in South Korea. More so, an ethnography research conducted by Mahalingam et al. (2015) on two metro railway stations projects in India, exemplified the effect of BIM in the decision-making process leading to precise planning and reduced contract duration. The rapid growth in BIM adoption in the Swedish construction industry was elucidated in a study by Samuelson and Björk (2014) while Zhang et al. (2016) developed a framework to facilitate the integration of BIM and sustainability studies into the curriculum development for civil engineering students. Also, some set of principal areas or factors to consider in the adoption and implementation of BIM in an organization has been developed (Won et al. 2013).

Conclusively, there have been a steady increase in the number of BIM articles published under the category - "BIM learning, adoption \& practice" between 2013 and 2016; however, prior to this period, less than four BIM articles in this research area were disseminated. Meanwhile, BIM research in this category had focused mostly on RC5.1 - "BIM usage and adoption" and RC5.11 - "BIM practice paradigms \& governance approach" (with 13 articles each); we can then surmise that BIM being a novel approach in the built environment has led BIM authors to direct their attention to the core of its adoption and practice and to set up a governance mechanism to facilitate its implementation. Next, are research themes such as RC5.2 - "BIM curriculum development" and RC5.4 - "BIM teaching and support" with 7 articles each; this analysis reveals the increasing spotlight on the development of BIM module and training for undergraduate university students and professionals who would be the fulcrum in the adoption and implementation of BIM.

Therefore, based on the analysis of this category, we deduce the critical drivers of BIM adoption to include: (1) The development of undergraduate BIM curriculum and modules which should incorporate the practical aspects of BIM to train students who are potential "recruits" to the industry. (2) The institution of a training and support programs such as workshops, seminars, and conferences on BIM to aid the skill sets and development of inhouse personnel on the use of BIM. (3) Establishment of a working BIM governance mechanism or framework to support its overall implementation and increase the success rate of BIM-enable projects.

\subsection{Building design and energy conformance (RC2)}

The research category of "Building design and Energy conformance (RC2)" is another major area of immense publication and interest among BIM authors and in the 
construction industry with $65 \mathrm{BIM}$ articles as at the year 2016. The bibliometric analysis of its research areas and themes crystallize out nine (9) main BIM research themes which are: $R C 2.1$ - "building energy regulations" (McGuire et al. 2016; Thompson, Bank 2010); RC2.2 "code checking \& compliance" (Dimitrov, GolparvarFard 2015; Jung et al. 2015; Li et al. 2014); RC2.3 "building envelope, cost and energy performance" (Ahn et al. 2014; Asl et al. 2015; Chardon et al. 2016; Gökçe, H. U., Gökçe, K. U. 2013; Migilinskas et al. 2016); and RC2.4 - "energy management and analysis" (Gökce, $\mathrm{H}$. U., Gökce, K. U. 2014a; Kim, Anderson 2013; Kim, Yu 2016a; Lee et al. 2016).

Meanwhile, other preeminent research themes in this category include: RC2.5 - "structural analysis and design" (Bosché, Guenet 2014; Ham, Golparvar-Fard 2015; Lee et al. 2012a; Marzouk, Abdelaty 2014b); RC2.6 "building rating systems and assessments" (Basbagill et al. 2013; Oti et al. 2016; Ryu, Park 2016); RC2.7 "tracking of design changes and errors" (Dong et al. 2014; Lee et al. 2015a; Pilehchian et al. 2015); RC2.8 "daylighting profiling" (Welle et al. 2012), and RC2.9 "design validation and coordination" (Gimenez et al. 2016; Kim, Jeon 2012; Kim, Yu 2016b; Lee et al. 2012b; Shin, Cho 2015). Meanwhile, a bibliometric analysis of this category reveals more BIM publications in areas such as RC2.5 - "structural analysis and design" with 13 articles and RC2.3 - "building envelope, cost, and energy performance" with $12 \mathrm{BIM}$ articles.

Other aspects such as $R C 2.9$ - "design validation and coordination" and RC2.4 - "energy management and analysis" with 12 and 10 BIM articles respectively are current research directions in this category. Authors with research interest in "building design and energy conformance (RC2)" tends to center the studies mostly in these four main themes; and it signifies the increasing importance of developing BIM models for projects which are of (1) high structural design and integrity; (2) validated and vetted designs; and (3) a profiled and efficient energy usage and management.

Studies such as Ham and Golparvar-Fard (2015) developed a system using the gbXML schema to improve the energy performance of buildings while query systems based on IFC schema have also been advanced (Gao et al. 2015; Kang 2017; Solihin et al. 2017). More so, Kim et al. (2015c) developed a physical BIM library to aid the simulation of building component thermal conditions; while Kim et al. (2015b) observed that most energy analysis for buildings are done when the design has been completed. Hence, they developed an IFC framework to map building materials with energy properties of which the results shows "significant gain in accuracy". Meanwhile, H. U. Gökçe and K. U. Gökçe (2014b) introduced an efficient integrated energy platform for the residential buildings, while Shiau et al. (2012) utilized Ecotect software to improve the energy usage of old structures; and studies such as Cho et al. (2014) and Knight et al.
(2010) discusses the benefits of BIM in HVAC design and placement of reinforcement bars in concrete slabs respectively. Other researches focus include case studies reviews on structural BIM (Robinson 2007); quantitative assessment of carbon-dioxide emission (Jun et al. 2015); strategies for design error management (Al Hattab et al. 2015); creation of BIM models from laser scanner data (Xiong et al. 2013), and the design of track alignment using BIM (Huang et al. 2011).

\subsection{Sustainability (RC9)}

Sustainability is one of the increasing and preeminent issues in the construction industry and in other sectors of the global economy, while the concept of sustainable development represents a pyramid shift in the three-wheel drive of construction projects otherwise known as the "project management triangle" which are the time, cost and quality. The adoption and implementation of sustainable practices in construction ensure such projects meets its environmental, social and economic needs, considerations and implementation. BIM publications in this category are on the increase since the year 2011 till date with ten (10) main research themes has identified by the bibliometric analysis of this category articles' corpus.

The predominant research areas in this category include: RC9.1 - "sustainability performance of building" (Jrade, Jalaei 2013; Kreiner et al. 2015); RC9.2 - "environmental impact evaluation" (Lee et al. 2015b); RC9.3 "integrating BIM and LEED" (Azhar et al. 2011; Jalaei, Jrade 2015; Wu, Issa 2015); RC9.4 - "sustainable energy usage" (Azzi et al. 2015; Liu et al. 2015a); RC9.5"BIM-based decision support for master planning" (Kim et al. 2015d); RC9.6 - "sustainability appraisal" (Oti, Tizani 2015; Wong, Kuan 2014); RC9.7 - "indoor environmental quality (IEQ)" (Marzouk, Abdelaty 2014a); RC9.8 - "sustainable design and construction" (Bynum et al. 2013; Geyer 2012); RC9.9 - "3D analysis of lifecycle assessment" (Inyim et al. 2015; Kulahcioglu et al. 2012); and RC9.10 - "sustainable material selection" (Bank et al. 2011).

Prominent studies on sustainability issues in construction projects include Oti et al. (2016) who utilized the BIM API extension to embed sustainability issues to simulate the assessment of structural steel design; while Oh et al. (2015) in a case study approach, reviewed the enhancement of the design quality of a hospital design using an integrated system. Ilhan and Yaman (2016) advanced an IFC-based sustainability decision support system ("Green building assessment tool (GBAT)") of which green building data can be certified for BREEAM (Building Research Establishment Environmental Assessment Method).

\section{Research limitations}

The main limitation of this study's bibliometric analysis is the literature search strategy.That is, the choice of the scientific database (ISI Web of Science) which despite 
being "the world's leading citation database, offering a high level of accuracy and detail on a multidisciplinary scale" (Neto et al. 2016), it may only represent a fraction of the whole population. Another drawback might evolve from the exclusion of articles not written in English and some other false positives in the removal of some unrelated papers or the categorization of items within research areas.

\section{Conclusions}

The advent of BIM in the construction industry has brought about tremendous improvement in the process and system of coordinating construction projects and enabling collaboration among professionals both in the academia and the industry. The research's objectives were to investigate and evaluate the extant literature on BIM; and identify the trends, research impacts, research categories, BIM funding structure and other parameters of the research publications' corpus through a bibliometric analysis of 445 BIM articles; which are of high impact factors from the Web of Science which Neto et al. (2016) regarded as the "largest and most reliable source for academic publications".

The level and depth of the bibliometric analysis is considered as the prime distinction between this study and previous literature reviews on BIM literature; which allows academics, industry practitioners and readers to track the funding structure of BIM research, the research categories and the project sectors for which BIM has had the most impact; and have an overview of how BIM literature has evolved over the years. Moreover, based on the bibliometric analysis of the BIM articles, there was a marked increase in the number of BIM articles from 17 papers in 2010 to almost double value of 32 BIM articles in 2011 and the volume of BIM publications crossed the threshold of a hundred (100) BIM papers in the year 2015 with a total of 114 published BIM articles.

Also, an analysis of the articles' corpus journal list reveals Automation in Construction as the journal with most published work on BIM themes. More so, the tremendous impacts of BIM implementation in the construction industry were felt most in the building and housing project sector with more than 340 BIM articles addressing issues such as building elements and components, etc. Other project areas such as transportation, environment, and even the educational sector had been positively influenced by the adoption of BIM with several articles developing frameworks, models, systems and providing innovation solutions to improve the identified sectors using BIM.

More so, after the bibliometric analysis of the BIM articles, we further endeavor to classify them into 10 research categories, and the core research categories based on published BIM works are: (1) Construction and project management; (2) BIM learning, adoption, and practice; (3) BIM design and energy conformance; (4) BIM software and data schema; and (5) BIM model development. The five research categories had more than 50 BIM articles each and are considered the salient BIM research areas. Nevertheless, research areas such as facility management and sustainability can be classified as the latest trends in BIM research with increased output in publications in those two categories since the year 2014.

Furthermore, an analysis of funding structure of BIM articles reveals that more than 50 percent of the 445 analyzed articles received some funding to undertake the research; while further funding inquiry-based research category analysis and research origin analysis reveals thus: (1) there has been a significant increase in funded articles since the year 2013 till date; (2) BIM articles relating to research categories such as "building design and energy conformance", "construction and project management", "BIM software \& data schema" and "BIM model development" have received more funding (with at least 30 funded articles); (3) the Republic of Korea and the United States with 68 and 45 funded BIM publications are the countries whose BIM researchers have received a sizeable number of research grants to undertake BIMrelated research. However, funding analysis by regions shows Asia with 112 articles, Europe with 57 articles and North America with 55 BIM articles are the regions with the most funded BIM publications.

Moreover, a further analysis of the research categories reveals 107 research themes. The analysis unfolds trending research themes and direction, both in the academia and in the industry and these include: "BIM usage and adoption (RC5.1)", "BIM practice paradigms \& governance approach (RC5.11)"; "structural analysis and design (RC6.9)", "building envelope, cost and energy performance (RC2.3)", "design validation and coordination (RC2.9)"; and "energy management and analysis (RC2.1)" with more than 10 BIM articles each. The result is a pointer to the fact that more studies are being conducted to investigate BIM adoption and implementation in several countries and domains, and in countries where BIM has reached an acceptance level of adoption and compliance, such as the US, research tends to focus on developing and introducing BIM governance mechanisms. Other findings evaluate the salient research methodology used in previous studies and the available BIM software and data schema while the discussion centered on the established BIM research categories and themes.

However, for potential future research, researchers can select one or more research category or theme and undertake a review using the same or different research approach. The study's bibliometric analysis identified some essential gaps and opportunities for future research in BIM field. Research areas such as: (1) BIM-Sustainability issues integration; (2) Using BIM for environmental and socio-economic evaluations; (3) integrating BIM and Augmented reality during the construction phase; (4) Ontology and semantic web; (5) Mapping of BIM \& domain knowledge; and (5) information extraction are currently 
not receiving adequate considerations from researchers in the academia and those in the industry. It is noteworthy that these research areas when given due attention have the benefits of enhancing the growth of the construction sector and boost its productivity level. Conclusively, the study would assist BIM researchers and other academics to recognize the pattern and structure of BIM research and field and help them to pinpoint areas of research interest for their future research works.

Funding

This research study is supported through funding by the Sustainable City Laboratory under the auspice of the Department of Building and Real Estate, The Hong Kong Polytechnic University, Hong Kong.

\section{Disclosure statement}

The authors state that there is no financial, professional or personal interest or benefit arising from the direct applications of their research.

\section{References}

Abedi, M.; Fathi, M. S.; Mirasa, A. K.; Rawai, N. M. 2016. Integrated collaborative tools for precast supply chain management, Scientia Iranica 23(2): 429-448. https://doi.org/10.24200/sci.2016.2129

Ahn, Y. H.; Cho, C.-S.; Lee, N. 2013. Building Information Modeling: Systematic course development for undergraduate construction students, Journal of Professional Issues in Engineering Education and Practice 139(4): 290-300. https://doi.org/10.1061/(ASCE)EI.1943-5541.0000164

Ahn, K.-U.; Kim, Y.-J.; Park, C.-S.; Kim, I.; Lee, K. 2014. BIM interface for full vs. semi-automated building energy simulation, Energy and Buildings 68(B): 671-678. https://doi.org/10.1016/j.enbuild.2013.08.063

Ahn, Y. H.; Kwak, Y. H.; Suk, S. J. 2016. Contractors' transformation strategies for adopting Building Information Modeling, Journal of Management in Engineering 32(1). https://doi.org/10.1061/(ASCE)ME.1943-5479.0000390

Aibinu, A.; Venkatesh, S. 2014. Status of BIM adoption and the BIM experience of cost consultants in Australia, Journal of Professional Issues in Engineering Education Practice 140: $1-10$. https://doi.org/10.1061/(ASCE)EI.1943-5541.0000193

Ajam, M.; Alshawi, M.; Mezher, T. 2010. Augmented process model for e-tendering: Towards integrating object models with document management systems, Automation in Construction 19(6): 762-778.

https://doi.org/10.1016/j.autcon.2010.04.001

Ajayi, S. O.; Oyedele, L. O.; Bilal, M.; Akinade, O. O.; Alaka, H. A. H. A.; Owolabi, H. A.; Kadiri, K. O. 2015. Waste effectiveness of the construction industry: Understanding the impediments and requisites for improvements, Resources Conservation and Recycling 102: 101-112. https://doi.org/10.1016/j.resconrec.2015.06.001

Akinade, O. O.; Oyedele, L. O.; Bilal, M.; Ajayi, S. O.; Owolabi, H. A.; Alaka, H. A.; Bello, S. A. 2015. Waste minimisation through deconstruction: A BIM based DeConstructability Assessment Score (BIM-DAS), Resources Conservation and Recycling 105: 167-176. https://doi.org/10.1016/j.resconrec.2015.10.018

Al Hattab, M.; Hamzeh, F.; Hattab, M. A.; Hamzeh, F. 2015. Using social network theory and simulation to compare traditional versus BIM-lean practice for design error man- agement, Automation in Construction 52: 59-69. https://doi.org/10.1016/j.autcon.2015.02.014

Alci, N. I. A. Z. S.; Sampaio, A. Z. 2015. The introduction of the BIM concept in civil engineering curriculum, International Journal of Engineering Education 31(1): 302-315.

Alreshidi, E.; Mourshed, M.; Rezgui, Y. 2016. Cloud-Based BIM governance platform requirements and specifications: Software engineering approach using BPMN and UML, Journal of Computing in Civil Engineering 30(4). https://doi.org/10.1061/(ASCE)CP.1943-5487.0000539

Altaf, M. S.; Hashisho, Z.; Al-Hussein, M. 2014. A method for integrating occupational indoor air quality with building information modeling for scheduling construction activities, Canadian Journal of Civil Engineering 41(3): 245251. https://doi.org/10.1139/cjce-2013-0230

Aram, S.; Eastman, C.; Sacks, R. 2013. Requirements for BIM platforms in the concrete reinforcement supply chain, $\mathrm{Au}$ tomation in Construction 35: 1-17. https://doi.org/10.1016/j.autcon.2013.01.013

Arayici, Y.; Coates, P.; Koskela, L.; Kagioglou, M.; Usher, C.; O'Reilly, K. 2011. Technology adoption in the BIM implementation for lean architectural practice, Automation in Construction 20(2): 189-195. https://doi.org/10.1016/j.autcon.2010.09.016

Asl, M. R.; Zarrinmehr, S.; Bergin, M.; Yan, W. 2015. BPOpt: A framework for BIM-based performance optimization, Energy and Buildings 108: 401-412. https://doi.org/10.1016/j.enbuild.2015.09.011

Azhar, S. 2011. Building Information Modeling (BIM): Trends, benefits, risks, and challenges for the AEC industry, Leadership and Management in Engineering 11(3): 241-252. https://doi.org/10.1061/(ASCE)LM.1943-5630.0000127

Azhar, S.; Carlton, W. A.; Olsen, D.; Ahmad, I. 2011. Building information modeling for sustainable design and LEED (R) rating analysis, Automation in Construction 20(2): 217-224. https://doi.org/10.1016/j.autcon.2010.09.019

Azzi, M.; Duc, H.; Ha, Q. P. 2015. Toward sustainable energy usage in the power generation and construction sectors A case study of Australia, Automation in Construction 59: 122-127. https://doi.org/10.1016/j.autcon.2015.08.001

Babic, N. C.; Podbreznik, P.; Rebolj, D. 2010. Integrating resource production and construction using BIM, Automation in Construction 19(5, SI): 539-543. https://doi.org/10.1016/j.autcon.2009.11.005

Bank, L. C.; Thompson, B. P.; McCarthy, M. 2011. Decisionmaking tools for evaluating the impact of materials selection on the carbon footprint of buildings, Carbon Management 2(4): 431-441. https://doi.org/10.4155/CMT.11.33

Bansal, V. K. 2011. Use of GIS and topology in the identification and resolution of space conflicts, Journal of Computing in Civil Engineering 25(2): 159-171. https://doi.org/10.1061/(ASCE)CP.1943-5487.0000075

Basbagill, J.; Flager, F.; Lepech, M.; Fischer, M. 2013. Application of life-cycle assessment to early stage building design for reduced embodied environmental impacts, Building and Environment 60: 81-92. https://doi.org/10.1016/j.buildenv.2012.11.009

Becerik-Gerber, B.; Kensek, K. 2010. Building Information Modeling in architecture, engineering, and construction: Emerging research directions and trends, Journal of Professional Issues in Engineering Education and Practice 136(3): 139-147. https://doi.org/10.1061/(ASCE)EI.1943-5541.0000023

Becerik-Gerber, B. A.; Ku, K.; Jazizadeh, F. 2012a. BIM-enabled virtual and collaborative construction engineering and management, Journal of Professional Issues in Engineering Education and Practice 138(3): 234-245. https://doi.org/10.1061/(ASCE)EI.1943-5541.0000098 
Becerik-Gerber, B.; Jazizadeh, F.; Li, N.; Calis, G. 2012 b. Application areas and data requirements for BIM-enabled facilities management, Journal of Construction Engineering and Management 138(3): 431-442. https://doi.org/10.1061/(ASCE)CO.1943-7862.0000433

Belsky, M.; Eastman, C.; Sacks, R.; Venugopal, M.; Aram, S.; Yang, D. 2014. Interoperability for precast concrete building models, PCI Journal, 144-155. https://doi.org/10.15554/pcij.03012014.144.155

Borrmann, A.; Kolbe, T. H.; Donaubauer, A.; Steuer, H.; Jubierre, J. R.; Flurl, M. 2015. Multi-scale geometricsemantic modeling of shield tunnels for GIS and BIM applications, Computer-Aided Civil and Infrastructure Engineering 30(4): 263-281. https://doi.org/10.1111/mice. 12090

Bosché, F.; Guenet, E. 2014. Automating surface flatness control using terrestrial laser scanning and building information models, Automation in Construction 44: 212-226. https://doi.org/10.1016/j.autcon.2014.03.028

Bradley, A.; Li, H.; Lark, R.; Dunn, S. 2016. BIM for infrastructure: An overall review and constructor perspective, Automation in Construction 71: 139-152. https://doi.org/10.1016/j.autcon.2016.08.019

Brynjolfsson, E.; Hu, Y. J.; Simester, D. 2011. Goodbye Pareto principle, hello long tail: The effect of search costs on the concentration of product sales, Management Science 57(8): 1373-1386. https://doi.org/10.1287/mnsc.1110.1371

Bynum, P.; Issa, R. R. A.; Olbina, S. 2013. Building Information Modeling in support of sustainable design and construction, Journal of Construction Engineering and Management 139(1): 24-34. https://doi.org/10.1061/(ASCE)CO.1943-7862.0000560

Chang, J.-R.; Lin, H.-S. 2016. Underground pipeline management based on road information modeling to assist in road management, Journal of Performance of Constructed Facilities 30(1). https://doi.org/10.1061/(ASCE)CF.1943-5509.0000631

Chardon, S.; Brangeon, B.; Bozonnet, E.; Inard, C. 2016. Construction cost and energy performance of single family houses: From integrated design to automated optimization, Automation in Construction 70: 1-13. https://doi.org/10.1016/j.autcon.2016.06.011

Chen, H.-M.; Hou, C. 2014. Asynchronous online collaboration in BIM generation using hybrid client-server and P2P network, Automation in Construction 45: 72-85. https://doi.org/10.1016/j.autcon.2014.05.007

Chen, L.; Luo, H. 2014. A BIM-based construction quality management model and its applications, Automation in Construction 46: 64-73. https://doi.org/10.1016/j.autcon.2014.05.009

Chen, S.; Grif, F. H. B.; Chen, P.-H.; Chang, L.; Griffis, F. H. H. 2013. A framework for an automated and integrated project scheduling and management system, Automation in Construction 35: 89-110. ttps://doi.org/10.1016/j.autcon.2013.04.002

Chien, K. F.; Wu, Z. H.; Huang, S. C. 2014. Identifying and assessing critical risk factors for BIM projects: Empirical study, Automation in Construction 45: 1-15. https://doi.org/10.1016/j.autcon.2014.04.012

Cho, Y. S.; Lee, S. I.; Bae, J. S. 2014. Reinforcement placement in a concrete slab object using structural building information modeling, Computer-Aided Civil and Infrastructure Engineering 29(1): 47-59. https://doi.org/10.1111/j.1467-8667.2012.00794.x

Choi, J.; Kim, I. 2015. Development of an open BIM-based legality system for building administration permission services, Journal of Asian Architecture and Building Engineering 14(3): 577-584.

https://doi.org/10.3130/jaabe.14.577
Choi, J. J.; Choi, J. J.; Kim, I. 2014. Development of BIMbased evacuation regulation checking system for high-rise and complex buildings, Automation in Construction 46: 38-49. https://doi.org/10.1016/j.autcon.2013.12.005

Dave, B.; Kubler, S.; Främling, K.; Koskela, L. 2016. Opportunities for enhanced lean construction management using Internet of Things standards, Automation in Construction 61: 86-97. https://doi.org/10.1016/j.autcon.2015.10.009

Davies, R.; Harty, C. 2013. Implementing 'Site BIM': A case study of ICT innovation on a large hospital project, Automation in Construction 30: 15-24. https://doi.org/10.1016/j.autcon.2012.11.024

Deng, Y.; Cheng, J. C. P. P.; Anumba, C. 2016. Mapping between BIM and 3D GIS in different levels of detail using schema mediation and instance comparison, Automation in Construction 67: 1-21. https://doi.org/10.1016/j.autcon.2016.03.006

Dimitrov, A.; Golparvar-Fard, M. 2015. Segmentation of building point cloud models including detailed architectural/ structural features and MEP systems, Automation in Construction 51: 32-45. https://doi.org/10.1016/j.autcon.2014.12.015

Dong, B.; O’Neill, Z.; Li, Z. 2014. A BIM-enabled information infrastructure for building energy fault detection and diagnostics, Automation in Construction 44: 197-211. https://doi.org/10.1016/j.autcon.2014.04.007

Dossick, C. S.; Neff, G. 2010. Organizational divisions in BIMenabled commercial construction, Journal of Construction Engineering and Management 136(4): 459-467. https://doi.org/10.1061/(ASCE)CO.1943-7862.0000109

Du, J.; Liu, R.; Issa, R. R. A. 2014. BIM cloud score: Benchmarking BIM performance, Journal of Construction Engineering and Management 140(11): 1-13. https://doi.org/10.1061/(ASCE)CO.1943-7862.0000891

Eadie, R.; Browne, M.; Odeyinka, H.; McKeown, C.; McNiff, S. 2013. BIM implementation throughout the UK construction project lifecycle: An analysis, Automation in Construction 36: 145-151.

https://doi.org/10.1016/j.autcon.2013.09.001

Eastman, C.; Teicholz, P.; Sacks, R.; Liston, K. 2008. BIM handbook: a guide to building information modelling for owner, managers, designers, engineers, and contractors. New York: John Wiley \& Sons.

Faghihi, V.; Reinschmidt, K. F.; Kang, J. H. 2014. Construction scheduling using Genetic Algorithm based on Building Information Model, Expert Systems with Applications 41(16): 7565-7578. https://doi.org/10.1016/j.eswa.2014.05.047

Faghihi, V.; Reinschmidt, K. F.; Kang, J. H. 2016. Objectivedriven and Pareto Front analysis: Optimizing time, cost, and job-site movements, Automation in Construction 69: 79-88. https://doi.org/10.1016/j.autcon.2016.06.003

Fan, S.-L. 2014. Intellectual property rights in Building Information Modeling application in Taiwan, Journal of Construction Engineering and Management 140(3): 1-6. https://doi.org/10.1061/(ASCE)CO.1943-7862.0000808

Fan, S. L.; Skibniewski, M. J.; Hung, T. W. 2014. Effects of building information modeling during construction, Journal of Applied Science and Engineering 17(2): 157-166. https://doi.org/10.6180/jase.2014.17.2.06

Farr, E. R. P.; Piroozfar, P. A. E.; Robinson, D. 2014. BIM as a generic configurator for facilitation of customisation in the AEC industry, Automation in Construction 45: 119-125. https://doi.org/10.1016/j.autcon.2014.05.012

Fortner, B. B. 2008. Special report: Are you ready for BIM?, Civil Engineering: The Online Magazine of American Society of Civil Engineers.

Francom, T. C.; El Asmar, M. 2015. Project quality and change performance differences associated with the use of 
Building Information Modeling in design and construction projects: Univariate and multivariate analyses, Journal of Construction Engineering and Management 141(9). https://doi.org/10.1061/(ASCE)CO.1943-7862.0000992

Gao, G.; Liu, Y. S.; Wang, M.; Gu, M.; Yong, J. H. 2015. A query expansion method for retrieving online BIM resources based on Industry Foundation Classes, Automation in Construction 56: 14-25.

https://doi.org/10.1016/j.autcon.2015.04.006

Gelisen, G.; Griffis, F. H. 2014. Automated productivity-based schedule animation: Simulation-based approach to timecost trade-off analysis, Journal of Construction Engineering and Management 140(4): 1-10.

https://doi.org/10.1061/(ASCE)CO.1943-7862.0000674

Geyer, P. 2012. Systems modelling for sustainable building design, Advanced Engineering Informatics 26(4): 656-668. https://doi.org/10.1016/j.aei.2012.04.005

Giel, B. K.; Issa, R. R. A. 2013. Return on investment analysis of using Building Information Modeling in construction, Journal of Computing in Civil Engineering 27(5): $511-521$. https://doi.org/10.1061/(ASCE)CP.1943-5487.0000164

Giel, B.; Issa, R. R. A. 2016. Framework for evaluating the BIM competencies of facility owners, Journal of Management in Engineering 32(1). https://doi.org/10.1061/(ASCE)ME.1943-5479.0000378

Gilkinson, N.; Raju, P.; Kiviniemi, A.; Chapman, C.; Raju, P.; Chapman, C. 2015. Building information modelling: the tide is turning, Proceedings of the Institution of Civil Engineers-Structures and Buildings 168(2): 81-93. https://doi.org/10.1680/stbu.12.00045

Gimenez, L.; Robert, S.; Suard, F.; Zreik, K. 2016. Automatic reconstruction of $3 \mathrm{D}$ building models from scanned $2 \mathrm{D}$ floor plans, Automation in Construction 63: 48-56. https://doi.org/10.1016/j.autcon.2015.12.008

Gnaur, D.; Svidt, K.; Thygesen, M. K. 2015. Developing students' collaborative skills in interdisciplinary learning environments, International Journal of Engineering Education 31(1): 257-266.

Goedert, J. D.; Meadati, P. 2008. Integrating construction process documentation into Building Information Modeling, Journal of Construction Engineering and Management 134(7): 509-516. https://doi.org/10.1061/(ASCE)07339364(2008)134:7(509)

Gökçe, H. U.; Gökçe, K. U. 2013. Holistic system architecture for energy efficient building operation, Sustainable Cities and Society 6(1): 77-84. https://doi.org/10.1016/j.scs.2012.07.003

Gökçe, H. U.; Gökçe, K. U. 2014a. Integrated system platform for energy efficient building operations, Journal of Computing in Civil Engineering 28(6): 1-11. https://doi.org/10.1061/(ASCE)CP

Gökce, H. U.; Gökce, K. U. 2014b. Multi-dimensional energy monitoring, analysis and optimization system for energy efficient building operations, Sustainable Cities and Society 10: 161-173. https://doi.org/10.1016/j.scs.2013.08.004

Grilo, A. A.; Jardim-Goncalves, R. 2011. Challenging electronic procurement in the AEC sector: A BIM-based integrated perspective, Automation in Construction 20(2): 107-114. https://doi.org/10.1016/j.autcon.2010.09.008

Grilo, A.; Jardim-Goncalves, R. 2013. Cloud-Marketplaces: Distributed e-procurement for the AEC sector, Advanced Engineering Informatics 27(2): 160-172. https://doi.org/10.1016/j.aei.2012.10.004

Grilo, A.; Zutshi, A.; Jardim-Goncalves, R.; Steiger-Garcao, A. 2013. Construction collaborative networks: the case study of a building information modelling-based office building project, International Journal of Computer Integrated
Manufacturing 26(1-2): 152-165

https://doi.org/10.1080/0951192X.2012.681918

$\mathrm{Gu}, \mathrm{N}$.; London, K. 2010. Understanding and facilitating BIM adoption in the AEC industry, Automation in Construction 19(8): 988-999.

https://doi.org/10.1016/j.autcon.2010.09.002

Ham, Y.; Golparvar-Fard, M. 2015. Mapping actual thermal properties to building elements in gbXML-based BIM for reliable building energy performance modelling, Automation in Construction 49: 214-224.

https://doi.org/10.1016/j.autcon.2014.07.009

Han, K. K.; Cline, D.; Golparvar-Fard, M. 2015. Formalized knowledge of construction sequencing for visual monitoring of work-in-progress via incomplete point clouds and low-LoD 4D BIMs, Advanced Engineering Informatics 29(4): 889-901. https://doi.org/10.1016/j.aei.2015.10.006

Hanna, A.; Boodai, F.; El Asmar, M. 2013. State of practice of Building Information Modeling in mechanical and electrical construction industries, Journal of Construction Engineering and Management 139(10): 1-8.

https://doi.org/10.1061/(ASCE)CO.1943-7862.0000747

Hanna, A. S.; Yeutter, M.; Aoun, D. G. 2014. State of practice of Building Information Modeling in the electrical construction industry, Journal of Construction Engineering and Management 140(12).

https://doi.org/10.1061/(ASCE)CO.1943-7862.0000893

Hartmann, T.; Van Meerveld, H.; Vossebeld, N.; Adriaanse, A. 2012. Aligning building information model tools and construction management methods, Automation in Construction 22: 605-613.

https://doi.org/10.1016/j.autcon.2011.12.011

Henry, A.; Tizani, W.; Oti, A. H.; Tizani, W.; Henry, A.; Tizani, W. 2015. BIM extension for the sustainability appraisal of conceptual steel design, Advanced Engineering Informatics 29(1): 28-46. https://doi.org/10.1016/j.aei.2014.09.001

Howard, R.; Björk, B. C. 2008. Building information modelling - Experts' views on standardisation and industry deployment, Advanced Engineering Informatics 22(2): 271-280. https://doi.org/10.1016/j.aei.2007.03.001

Hu, Z.-Z.; Zhang, X.-Y.; Wang, H.-W.; Kassem, M. 2016. Improving interoperability between architectural and structural design models: An industry foundation classes-based approach with web-based tools, Automation in Construction 66: 29-42.

https://doi.org/10.1016/j.autcon.2016.02.001

Huang, S.-F.; Chen, C.; Dzeng, R.-J. 2011. Design of track alignment using Building Information Modeling, Journal of Transportation Engineering 137(11): 823-830. https://doi.org/10.1061/(ASCE)TE.1943-5436.0000287

Ilhan, B.; Yaman, H. 2016. Green building assessment tool (GBAT) for integrated BIM-based design decisions, Automation in Construction 70: 26-37. https://doi.org/10.1016/j.autcon.2016.05.001

Inyim, P.; Rivera, J.; Zhu, Y. 2015. Integration of Building Information Modeling and economic and environmental impact analysis to support sustainable building design, Journal of Management in Engineering 31(1, SI): 1-10. https://doi.org/10.1061/(ASCE)ME.1943-5479.0000308

Irizarry, J.; Karan, E. P.; Jalaei, F. 2013. Integrating BIM and GIS to improve the visual monitoring of construction supply chain management, Automation in Construction 31: 241-254. https://doi.org/10.1016/j.autcon.2012.12.005

Jalaei, F.; Jrade, A. 2015. Integrating Building Information Modeling (BIM) and LEED system at the conceptual design stage of sustainable buildings, Sustainable Cities and Society 18: 95-107. https://doi.org/10.1016/j.scs.2015.06.007

Jaradat, S.; Whyte, J.; Luck, R. 2013. Professionalism in digitally mediated project work, Building Research and 
Information 41(1, SI): 51-59.

https://doi.org/10.1080/09613218.2013.743398

Jiang, L.; Leicht, R. M. 2015. Automated rule-based constructability checking: Case study of formwork, Journal of Management in Engineering 31(1): 1-10. https://doi.org/10.1061/(ASCE)ME.1943-5479.0000304

Johansson, M.; Roupe, M.; Bosch-Sijtsema, P. 2015. Realtime visualization of building information models (BIM), Automation in Construction 54: 69-82. https://doi.org/10.1016/j.autcon.2015.03.018

Jrade, A.; Jalaei, F. 2013. Integrating building information modelling with sustainability to design building projects at the conceptual stage, Building Simulation 6(4): 429-444. https://doi.org/10.1007/s12273-013-0120-0

Jun, H.; Lim, N.; Kim, M. 2015. BIM-based carbon dioxide emission quantity assessment method in Korea, Journal of Asian Architecture and Building Engineering 14(3): 569-576. https://doi.org/10.3130/jaabe.14.569

Jung, W.; Lee, G. 2016. Slim BIM charts for rapidly visualizing and quantifying levels of BIM adoption and implementation, Journal of Computing in Civil Engineering 30(4). https://doi.org/10.1061/(ASCE)CP.1943-5487.0000554

Jung, J.; Hong, S.; Yoon, S.; Kim, J.; Heo, J. 2015. Automated 3D wireframe modeling of indoor structures from point clouds using constrained least-squares adjustment for as-built BIM, Journal of Computing in Civil Engineering 30(1): 4015074. https://doi.org/10.1061/(ASCE)CP.1943-5487.0000556

Kang, T. W. 2017. Object composite query method using IFC and LandXML based on BIM linkage model, Automation in Construction 76: 14-23. https://doi.org/10.1016/j.autcon.2017.01.008

Kang, T. W.; Hong, C. H. 2015. A study on software architecture for effective BIM/GIS-based facility management data integration, Automation in Construction 54: 25-38. https://doi.org/10.1016/j.autcon.2015.03.019

Kang, L. S.; Kim, H. S.; Moon, H. S.; Kim, S.-K. K. 2016. Managing construction schedule by telepresence: Integration of site video feed with an active $\mathrm{nD}$ CAD simulation, Automation in Construction 68: 32-43. https://doi.org/10.1016/j.autcon.2016.04.003

Karan, E. P.; Irizarry, J. 2015. Extending BIM interoperability to preconstruction operations using geospatial analyses and semantic web services, Automation in Construction 53: 1-12. https://doi.org/10.1016/j.autcon.2015.02.012

Kim, J.-L. 2012. Use of BIM for effective visualization teaching approach in construction education, Journal of Professional Issues in Engineering Education and Practice 138(3): 214-223. https://doi.org/10.1061/(ASCE)EI.1943-5541.0000102

Kim, H.; Anderson, K. 2013. Energy modeling system using Building Information Modeling open standards, Journal of Computing in Civil Engineering 27(3): 203-211. https://doi.org/10.1061/(ASCE)CP.1943-5487.0000215

Kim, J.; Jeon, B. H. 2012. Design integrated parametric modeling methodology for Han-ok, Journal of Asian Architecture and Building Engineering 11(2): 239-243. https://doi.org/10.3130/jaabe.11.239

Kim, I.; Kim, J.; Seo, J. 2012. Development of an IFC-based IDF converter for supporting energy performance assessment in the early design phase, Journal of Asian Architecture and Building Engineering 11(2): 313-320. https://doi.org/10.3130/jaabe.11.313

Kim, H.; Anderson, K.; Lee, S.; Hildreth, J. 2013. Generating construction schedules through automatic data extraction using open BIM (building information modeling) technology, Automation in Construction 35: 285-295. https://doi.org/10.1016/j.autcon2013.05.020

Kim, C. C.; Son, H.; Kim, C. C. 2013. Automated construction progress measurement using a 4D building informa- tion model and 3D data, Automation in Construction 31: 75-82. https://doi.org/10.1016/j.autcon.2012.11.041

Kim, K.; Yu, J. 2016a. A process to divide curved walls in IFC-BIM into segmented straight walls for building energy analysis, Journal of Civil Engineering and Management 22(3): 333-345. https://doi.org/10.3846/13923730.2014.897975

Kim, K.; Yu, J. 2016b. BIM-based building energy load calculation system for designers, KSCE Journal of Civil Engineering 20(2): 549-563. https://doi.org/10.1007/s12205-015-1625-0

Kim, J.; Fischer, M.; Kunz, J.; Levitt, R. 2014. Sharing of temporary structures: Formalization and planning application, Automation in Construction 43: 187-194. https://doi.org/10.1016/j.autcon.2014.03.018

Kim, H.; Lee, H.-S.; Park, M.; Chung, B.; Hwang, S. 2015a. Information retrieval framework for hazard identification in construction, Journal of Computing in Civil Engineering 29(3): 1-10. https://doi.org/10.1061/(ASCE)CP.1943-5487.0000340

Kim, H.; Shen, Z.; Kim, I.; Kim, K.; Stumpf, A.; Yu, J. 2015 b. BIM IFC information mapping to building energy analysis (BEA) model with manually extended material information, Automation in Construction 68: 183-193. https://doi.org/10.1016/j.autcon.2016.04.002

Kim, J. B.; Jeong, W.; Clayton, M. J.; Haberl, J. S.; Yan, W. 2015c. Developing a physical BIM library for building thermal energy simulation, Automation in Construction 50: 16-28. https://doi.org/10.1016/j.autcon.2014.10.011

Kim, J. I.; Jung, J.; Fischer, M.; Orr, R. 2015d. BIM-based decision-support method for master planning of sustainable large-scale developments, Automation in Construction 58: 95-108. https://doi.org/10.1016/j.autcon.2015.07.003

Kim, M.-K.; Cheng, J. C. P.; Sohn, H.; Chang, C.-C. 2015e. A framework for dimensional and surface quality assessment of precast concrete elements using BIM and 3D laser scanning, Automation in Construction 49: 225-238. https://doi.org/10.1016/j.autcon.2014.07.010

Kim, H.; Shen, Z.; Moon, H.; Ju, K.; Choi, W. 2016a. Developing a 3D intelligent object model for the application of construction planning/simulation in a highway project, KSCE Journal of Civil Engineering 20(2): 538-548. https://doi.org/10.1007/s12205-015-0463-4

Kim, K.; Cho, Y.; Zhang, S. 2016b. Integrating work sequences and temporary structures into safety planning: Automated scaffolding-related safety hazard identification and prevention in BIM, Automation in Construction 70: 128-142. https://doi.org/10.1016/j.autcon.2016.06.012

Kim, M.-K.; Wang, Q.; Park, J.-W.; Cheng, J. C. P.; Sohn, H.; Chang, C.-C. 2016c. Automated dimensional quality assurance of full-scale precast concrete elements using laser scanning and BIM, Automation in Construction 72: 102 114. https://doi.org/10.1016/j.autcon.2016.08.035

Kim, S.; Park, C. H.; Chin, S. 2016d. Assessment of BIM acceptance degree of Korean AEC participants, KSCE Journal of Civil Engineering 20(4): 1163-1177. https://doi.org/10.1007/s12205-015-0647-y

Knight, M. D. 2008. Teams, contracts, \& BIM, Ashrae Journal 50(9): 72.

Knight, D.; Roth, S.; Rosen, S. L. 2010. Using BIM in HVAC design, Ashrae Journal 52(6): 24.

Kota, S.; Haberl, J. S.; Clayton, M. J.; Yan, W. 2014. Building Information Modeling (BIM)-based daylighting simulation and analysis, Energy and Buildings 81: 391-403. https://doi.org/10.1016/j.enbuild.2014.06.043

Kovacic, I.; Filzmoser, M.; Kiesel, K.; Oberwinter, L.; Mahdavi, A. 2015. BIM teaching as support to integrated design practice, Gradevinar 67(6): 537-546.

Kraatz, J. A.; Hampson, K. D. 2013. Brokering innovation to better leverage R\&D investment, Building Research and 
Information 41(2): 187-197.

https://doi.org/10.1080/09613218.2013.749771

Kreiner, H.; Passer, A.; Wallbaum, H. 2015. A new systemic approach to improve the sustainability performance of office buildings in the early design stage, Energy and Buildings 109: 385-396.

https://doi.org/10.1016/j.enbuild.2015.09.040

Kulahcioglu, T.; Dang, J.; Toklu, C. 2012. A 3D analyzer for BIM-enabled Life Cycle Assessment of the whole process of construction, HVAC\&R Research 18: 283-293. https://doi.org/10.1080/10789669.2012.634264

Kumar, S. S.; Cheng, J. C. P. 2015. A BIM-based automated site layout planning framework for congested construction sites, Automation in Construction 59: 24-37. https://doi.org/10.1016/j.autcon.2015.07.008

Lee, S.; Yu, J. 2016. Comparative study of BIM acceptance between Korea and the United States, Journal of Construction Engineering and Management 142(3). https://doi.org/10.1061/(ASCE)CO.1943-7862.0001076

Lee, G.; Park, H. K.; Won, J. 2012a. D ${ }^{3}$ City project - Economic impact of BIM-assisted design validation, Automation in Construction 22: 577-586. https://doi.org/10.1016/j.autcon.2011.12.003

Lee, S.; Bae, J.; Cho, Y. S. 2012b. Efficiency analysis of setbased design with structural building information modeling (S-BIM) on high-rise building structures, Automation in Construction 23: 20-32. https://doi.org/10.1016/j.autcon.2011.12.008

Lee, G.; Park, Y. H.; Ham, S. 2013. Extended process to product modeling (xPPM) for integrated and seamless IDM and MVD development, Advanced Engineering Informatics 27(4): 636-651. https://doi.org/10.1016/j.aei.2013.08.004

Lee, C.; Son, J.; Lee, S. 2014. A system model for analyzing and accumulating construction work crew's productivity data using image processing technologies, Journal of Asian Architecture and Building Engineering 13(3): 547554. https://doi.org/10.3130/jaabe.13.547

Lee, H. W.; Oh, H.; Kim, Y.; Choi, K.; Woo, H. 2015a. Quantitative analysis of warnings in building information modeling (BIM), Automation in Construction 51: 23-31. https://doi.org/10.1016/j.autcon.2014.12.007

Lee, S.; Tae, S.; Roh, S.; Kim, T. 2015b. Green template for life cycle assessment of buildings based on Building Information Modeling: Focus on embodied environmental impact, Sustainability 7(12): 16498-16512. https://doi.org/10.3390/su71215830

Lee, D.; Cha, G.; Park, S. 2016. A study on data visualization of embedded sensors for building energy monitoring using BIM, International Journal of Precision Engineering and Manufacturing 17(6): 807-814. https://doi.org/10.1007/s12541-016-0099-4

Lewis, A. M.; Valdes-Vasquez, R.; Shealy, T. 2015. BIM energy modeling: Case study of a teaching module for sustainable design and donstruction dourses, Journal of Professional Issues in Engineering Education and Practice 141(2): 1-6. https://doi.org/10.1061/(ASCE)EI.1943-5541.0000230

Li, N.; Becerik-Gerber, B.; Krishnamachari, B.; Soibelman, L. 2014. A BIM centered indoor localization algorithm to support building fire emergency response operations, Automation in Construction 42: 78-89. https://doi.org/10.1016/j.autcon.2014.02.019

Lin, Y.-C. 2014. Construction 3D BIM-based knowledge management system: A case study, Journal of Civil Engineering and Management 20(2): 186-200. https://doi.org/10.3846/13923730.2013.801887

Liu, H.; Al-Hussein, M.; Lu, M. 2015a. BIM-based integrated approach for detailed construction scheduling under resource constraints, Automation in Construction 53: 29-43. https://doi.org/10.1016/j.autcon.2015.03.008
Liu, S.; Meng, X.; Tam, C. 2015b. Building information modeling based building design optimization for sustainability, Energy and Buildings 105: 139-153. https://doi.org/10.1016/j.enbuild.2015.06.037

Liu, Z.; Osniani, M.; Demian, P.; Baldwin, A. 2015c. A BIMaided construction waste minimisation framework, Automation in Construction 59: 1-23.

https://doi.org/10.1016/j.autcon.2015.07.020

Love, P. E. D.; Liu, J.; Matthews, J.; Sing, C.; Smith, J. 2015. Future proofing PPPs: Life-cycle performance measurement and Building Information Modelling, Automation in Construction 56: 26-35. https://doi.org/10.1016/j.autcon.2015.04.008

Lu, H.; Wang, H.; Xie, Y.; Li, H. 2016. Construction material safety-stock determination under nonstationary stochastic demand and random supply yield, IEEE Transactions on Engineering Management 63(2): 201-212. https://doi.org/10.1109/TEM.2016.2536146

Lu, W.; Fung, A.; Peng, Y.; Liang, C.; Rowlinson, S. 2014. Cost-benefit analysis of Building Information Modeling implementation in building projects through demystification of time-effort distribution curves, Building and Environment 82: 317-327. https://doi.org/10.1016/j.buildenv.2014.08.030

Mahalingam, A.; Yadav, A. K.; Varaprasad, J. 2015. Investigating the role of lean practices in enabling BIM adoption: Evidence from two Indian cases, Journal of Construction Engineering and Management 141(7). https://doi.org/10.1061/(ASCE)CO.1943-7862.0000982

Malekitabar, H.; Ardeshir, A.; Sebt, M. H.; Stouffs, R. 2016. Construction safety risk drivers: A BIM approach, Safety Science 82: 445-455. https://doi.org/10.1016/j.ssci.2015.11.002

Marsilio, M.; Cappellaro, G.; Cuccurullo, C. 2011. The intellectual structure of research into PPPs: A bibliometric analysis, Public Management Review 13(6): 763-782. https://doi.org/10.1080/14719037.2010.539112

Marzouk, M.; Abdelaty, A. 2014a. BIM-based framework for managing performance of subway stations, Automation in Construction 41: 70-77. https://doi.org/10.1016/j.autcon.2014.02.004

Marzouk, M.; Abdelaty, A. 2014b. Monitoring thermal comfort in subways using building information modelling, Energy and Buildings 84: 252-257. https://doi.org/10.1016/j.enbuild.2014.08.006

Marzouk, M.; Abubakr, A. 2016. Decision support for tower crane selection with building information models and genetic algorithms, Automation in Construction 61: 1-15. https://doi.org/10.1016/j.autcon.2015.09.008

Matthews, J.; Love, P. E. D.; Heinemann, S.; Chandler, R.; Rumsey, C.; Olatunji, O. 2015. Real time progress management: Re-engineering processes for cloud-based BIM in construction, Automation in Construction 58: 38-47. https://doi.org/10.1016/j.autcon.2015.07.004

McGuire, B.; Atadero, R.; Clevenger, C.; Ozbek, M. 2016. Bridge information modeling for inspection and evaluation, Journal of Bridge Engineering 21(4). https://doi.org/10.1061/(ASCE)BE.1943-5592.0000850

Migilinskas, D.; Balionis, E.; Dziugaite-Tumeniene, R.; Siupsinskas, G. 2016. An advanced multi-criteria evaluation model of the rational building energy performance, Journal of Civil Engineering and Management 22(6): 844-851. https://doi.org/10.3846/13923730.2016.1194316

Mom, M.; Tsai, M.-H.; Hsieh, S.-H. 2014. Developing critical success factors for the assessment of BIM technology adoption: Part II. Analysis and results, Journal of the Chinese Institute of Engineers 37(7): 859-868. https://doi.org/10.1080/02533839.2014.888798 
Moon, H.; Kim, H.; Kim, C.; Kang, L. 2014. Development of a schedule-workspace interference management system simultaneously considering the overlap level of parallel schedules and workspaces, Automation in Construction 39: 93-105. https://doi.org/10.1016/j.autcon.2013.06.001

Motamedi, A.; Mostafa, M.; Hammad, A.; Soltani, M. M.; Hammad, A. 2013. Localization of RFID-equipped assets during the operation phase of facilities, Advanced Engineering Informatics 27(4): 566-579. https://doi.org/10.1016/j.aei.2013.07.001

Nahangi, M.; Haas, C. T. 2014. Automated 3D compliance checking in pipe spool fabrication, Advanced Engineering Informatics 28(4): 360-369. https://doi.org/10.1016/j.aei.2014.04.001

Nahangi, M.; Haas, C. T. 2016. Skeleton-based discrepancy feedback for automated realignment of industrial assemblies, Automation in Construction 61: 147-161. https://doi.org/10.1016/j.autcon.2015.10.014

Nassar, K. 2012. Assessing Building Information Modeling estimating techniques using data from the classroom, Journal of Professional Issues in Engineering Education and Practice 138(3): 171-180. https://doi.org/10.1061/(ASCE)EI.1943-5541.0000101

Nath, T.; Attarzadeh, M.; Tiong, R. L. K.; Chidambaram, C.; Yu, Z. 2015. Productivity improvement of precast shop drawings generation through BIM-based process re-engineering, Automation in Construction 54: 54-68. https://doi.org/10.1016/j.autcon.2015.03.014

Neath, S.; Hulse, R.; Codd, A. 2014. Building information modelling in practice: Transforming Gatwick airport, UK, Proceedings of the Institution of Civil Engineers: Civil Engineering 167(2): 61-87. https://doi.org/10.1680/cien.13.00018

Neto, de C. e S. D.; Cruz, C. O.; Rodrigues, F.; Silva, P. 2016. Bibliometric analysis of PPP and PFI literature: Overview of 25 years of research, Journal of Construction Engineering and Management 142: 6016002. https://doi.org/10.1061/(ASCE)CO.1943-7862.0001163

Oh, M.; Lee, J.; Wan, S.; Jeong, Y. 2015. Integrated system for BIM-based collaborative design, Automation in Construction 58: 196-206. https://doi.org/10.1016/j.autcon.2015.07.015

Olatunji, S. O.; Olawumi, T. O.; Odeyinka, H. A. 2016a. Nigeria's public procurement law - Puissant issues and projected amendments, Public Policy and Administration Research 6(6): 73-85.

Olatunji, S. O.; Olawumi, T. O.; Ogunsemi, D. R. 2016b. Demystifying issues regarding Public Private Partnerships (PPP), Journal of Economics and Sustainable Development 7(11): 1-22.

Olatunji, S. O.; Olawumi, T. O.; Awodele, O. A. 2017a. Achieving Value for Money (VFM) in construction projects, Journal of Civil and Environmental Research 9(2): 54-64. Retrieved from: http://iiste.org/Journals/index.php/CER/ article/viewFile/35270/36293

Olatunji, S. O.; Olawumi, T. O.; Aje, I. O. 2017b. Rethinking partnering among quantity surveying firms in Nigeria, Journal of Construction Engineering and Management. https://doi.org/10.1061/(ASCE)CO.1943-7862.0001394

Olawumi, T. O. 2016. Establishment of critical causal factors for electrical cost estimating techniques, World Scientific News 53(3): 354-366.

Olawumi, T. O.; Ayegun, O. A. 2016. Are quantity surveyors competent to value for civil engineering works? Evaluating QSs' competencies and militating factors, Journal of Education and Practice 7(16): 1-16.

Olawumi, T. O.; Akinrata, E. B.; Arijeloye, B. T. 2016. Value management - Creating functional value for construction project: An exploratory study, World Scientific News 54: $40-59$.
Oti, A. H.; Tizani, W. 2015. BIM extension for the sustainability appraisal of conceptual steel design, Advanced Engineering Informatics 29(1): 28-46. https://doi.org/10.1016/j.aei.2014.09.001

Oti, A. H.; Tizani, W.; Abanda, F. H.; Jaly-Zada, A.; Tah, J. H. M. 2016. Structural sustainability appraisal in BIM, Automation in Construction 69: 44-58. https://doi.org/10.1016/j.autcon.2016.05.019

Pareto, V. 1964. Cours d'economie politique, in G. H. Bousquet, G. Busino (Eds.). Oevres Completes de Vilfredo Pareto, Vol. 1. Librairie Droz, Geneva. [Originally published in 1896].

Park, J.; Cai, H. 2017. WBS-based dynamic multi-dimensional BIM database for total construction as-built documentation, Automation in Construction 77: 15-23. https://doi.org/10.1016/j.autcon.2017.01.021

Peterson, F.; Hartmann, T.; Fruchter, R.; Fischer, M. 2011. Teaching construction project management with BIM support: Experience and lessons learned, Automation in Construction 20(2): 115-125. https://doi.org/10.1016/j.autcon.2010.09.009

Pikas, E.; Sacks, R.; Hazzan, O. 2013. Building Information Modeling education for construction engineering and management. II: Procedures and implementation case study, Journal of Construction Engineering and Management 139(11). https://doi.org/10.1061/(ASCE)CO.1943-7862.0000765

Pilehchian, B.; Staub-French, S.; Nepal, M. P. 2015. A conceptual approach to track design changes within a multidisciplinary building information modeling environment, Canadian Journal of Civil Engineering 42(2): 139-152. https://doi.org/10.1139/cjce-2014-0078

Poirier, E. A.; Staub-French, S.; Forgues, D. 2015. Measuring the impact of BIM on labor productivity in a small specialty contracting enterprise through action-research, $A u$ tomation in Construction 58: 74-84. https://doi.org/10.1016/j.autcon.2015.07.002

Porwal, A.; Hewage, K. N. 2012. Building Information Modeling-based analysis to minimize waste rate of structural reinforcement, Journal of Construction Engineering and Management 138(8): 943-954. https://doi.org/10.1061/(ASCE)CO.1943-7862.0000508

Ramos-Rodríguez, A.-R.; Ruíz-Navarro, J. 2004. Changes in the intellectual structure of strategic management research: a bibliometric study of the Strategic Management Journal, 1980-2000, Strategic Management Journal 25(10): 9811004. https://doi.org/10.1002/smj.397

Redmond, A.; Hore, A.; Alshawi, M.; West, R. 2012. Exploring how information exchanges can be enhanced through Cloud BIM, Automation in Construction 24: 175-183. https://doi.org/10.1016/j.autcon.2012.02.003

Rezgui, Y.; Beach, T.; Rana, O. 2013. A governance approach for BIM management across lifecycle and supply chains using mixed-modes of information delivery, Journal of Civil Engineering and Management 19(2): 239-258. https://doi.org/10.3846/13923730.2012.760480

Robinson, C. 2007. Structural BIM: Discussion, case studies and latest developments, Structural Design of Tall and Special Buildings 16(4): 519-533. https://doi.org/10.1002/tal.417

Ryu, H.-S.; Park, K.-S. 2016. A study on the LEED energy simulation process using BIM, Sustainability 8(2): 138 . https://doi.org/10.3390/su8020138

Sacks, R.; Barak, R. 2010. Teaching Building Information Modeling as an integral part of freshman year civil engineering education, Journal of Professional Issues in Engineering Education and Practice 136(1): 30-38. https://doi.org/10.1061/(ASCE)EI.1943-5541.0000003 
Sacks, R.; Pikas, E. 2013. Building Information Modeling education for construction engineering and management. I: Industry requirements, state of the art, and gap analysis, Journal of Construction Engineering and Management 139(11): 1-12. https://doi.org/10.1061/(ASCE)CO.1943-7862.0000759

Sacks, R.; Koskela, L.; Dave, B. A.; Owen, R. 2010a. Interaction of Lean and Building Information Modeling in construction, Journal of Construction Engineering and Management 136(9): 968-980.

https://doi.org/10.1061/(ASCE)CO.1943-7862.0000203

Sacks, R.; Radosavljevic, M.; Barak, R. 2010b. Requirements for building information modeling based lean production management systems for construction, Automation in Construction 19(5): 641-655. https://doi.org/10.1016/j.autcon.2010.02.010

Salleh, H.; Fung, W. P. 2014. Building Information Modelling application: focus-group discussion, Gradevinar 66(8): 705-714.

Sampaio, Z. A. 2015. The introduction of the BIM concept in civil engineering curriculum, International Journal of Engineering Education 31(1B): 302-315.

Samuelson, O.; Björk, B. C. 2014. A longitudinal study of the adoption of IT technology in the Swedish building sector, Automation in Construction 37: 182-190. https://doi.org/10.1016/j.autcon.2013.10.006

Samuelson, O.; Björk, B. 2016. Adoption processes for EDM, EDI and BIM technologies in the construction industry, Journal of Civil Engineering and Management 19(1): 172-187. https://doi.org/10.3846/13923730.2013.801888

Santos, R.; Costa, A. A.; Grilo, A. 2017. Bibliometric analysis and review of Building Information Modelling literature published between 2005 and 2015, Automation in Construction 80: 118-136. https://doi.org/10.1016/j.autcon.2017.03.005

Shiau, Y. C.; YuChi, C.; ChiHong, C.; PoYen, W. 2012. Using ecotect to improve energy conservation for older buildings, Research Journal of Chemistry and Environment 16(2): 162-171.

Shin, Y.; Cho, K. 2015. BIM application to select appropriate design alternative with consideration of LCA and LCCA, Mathematical Problems in Engineering. Article ID 281640. https://doi.org/10.1155/2015/281640

Solihin, W.; Eastman, C.; Lee, Y.-C. 2017. Multiple representation approach to achieve high-performance spatial queries of 3D BIM data using a relational database, Automation in Construction 81: 369-388. https://doi.org/10.1016/j.autcon.2017.03.014

Solnosky, R.; Parfitt, M. K.; Holland, R. J. 2014. IPD and BIMfocused capstone course based on AEC industry needs and involvement, Journal of Professional Issues in Engineering Education and Practice 140(4). https://doi.org/10.1061/(ASCE)EI.1943-5541.0000157

Succar, B. 2009. Building information modelling framework: A research and delivery foundation for industry stakeholders, Automation in Construction 18(3): 357-375. https://doi.org/10.1016/j.autcon.2008.10.003

Succar, B.; Kassem, M. 2015. Macro-BIM adoption: Conceptual structures, Automation in Construction 57: 64-79. https://doi.org/10.1016/j.autcon.2015.04.018

Succar, B.; Sher, W.; Williams, A. 2013. An integrated approach to BIM competency assessment, acquisition and application, Automation in Construction 35: 174-189. https://doi.org/10.1016/j.autcon.2013.05.016

Sun, J.; Wang, L. 2015. The interaction between BIM's promotion and interest game under information asymmetry, Journal of Industrial and Management Optimization 11(4): 1301-1319. https://doi.org/10.3934/jimo.2015.11.1301

Tan, Y.; Song, Y.; Liu, X.; Wang, X.; Cheng, J. C. P. 2017. A BIMbased framework for lift planning in topsides disassembly of offshore oil and gas platforms, Automation in Construction 79: 19-30. https://doi.org/10.1016/j.autcon.2017.02.008
Tashakkori, H.; Rajabifard, A.; Kalantari, M. 2015. A new $3 \mathrm{D}$ indoor/outdoor spatial model for indoor emergency response facilitation, Building and Environment 89(1): 170-182. https://doi.org/10.1016/j.buildenv.2015.02.036

Taylor, J. E.; Bernstein, P. G. 2009. Paradigm trajectories of Building Information Modeling practice in project networks, Journal of Management in Engineering 25(2): 69-76. https://doi.org/10.1061/(ASCE)0742-597X(2009)25:2(69)

Thompson, B. P.; Bank, L. C. 2010. Use of system dynamics as a decision-making tool in building design and operation, Building and Environment 45(4): 1006-1015. https://doi.org/10.1016/j.buildenv.2009.10.008

Tsai, M. Md, A. M.; Kang, S.-C.; Hsieh, S.; Matin, A. 2014a. Workflow re-engineering of design-build projects using a BIM tool, Journal of the Chinese Institute of Engineers 37(1): 88-102. https://doi.org/10.1080/02533839.2012.751302

Tsai, M.-H.; Mom, M.; Hsieh, S.-H. 2014b. Developing critical success factors for the assessment of BIM technology adoption: part I. Methodology and survey, Journal of the Chinese Institute of Engineers 37(7): 845-858. https://doi.org/10.1080/02533839.2014.888798

Tserng, H.-P.; Ho, S.-P.; Jan, S.-H. 2014. Developing BIM-assisted as-built schedule management system for general contractors, Journal of Civil Engineering and Management 20(1): 47-58. https://doi.org/10.3846/13923730.2013.851112

Turkan, Y.; Bosche, F.; Haas, C. T.; Haas, R. 2013. Toward automated earned value tracking using 3D imaging tools, Journal of Construction Engineering and Management 139(4): 423-433. https://doi.org/10.1061/(ASCE)CO.1943-7862.0000629

Volk, R.; Stengel, J.; Schultmann, F. 2014. Building Information Modeling (BIM) for existing buildings - literature review and future needs, Automation in Construction 38: 109-127. https://doi.org/10.1016/j.autcon.2013.10.023

Wang, L.; Leite, F. 2014. Process-oriented approach of teaching Building Information Modeling in construction management, Journal of Professional Issues in Engineering Education and Practice 140(4).

https://doi.org/10.1061/(ASCE)EI.1943-5541.0000203

Wang, L.; Leite, F. 2016. Process knowledge capture in BIM-based mechanical, electrical, and plumbing design coordination meetings, Journal of Computing in Civil Engineering 30(2).

https://doi.org/10.1061/(ASCE)CP.1943-5487.0000484

Wang, W.-C.; Weng, S.-W.; Wang, S.-H.; Chen, C.-Y. 2014a. Integrating building information models with construction process simulations for project scheduling support, Automation in Construction 37: 68-80.

https://doi.org/10.1016/j.autcon.2013.10.009

Wang, X.; Yung, P.; Luo, H.; Truijens, M. 2014b. An innovative method for project control in LNG project through 5D CAD: A case study, Automation in Construction 45: 126-135. https://doi.org/10.1016/j.autcon.2014.05.011

Wang, S.-H.; Wang, W.-C.; Wang, K.-C.; Shih, S.-Y. 2015. Applying building information modeling to support fire safety management, Automation in Construction 59: 158-167. https://doi.org/10.1016/j.autcon.2015.02.001

Watson, A. 2011. Digital buildings - challenges and opportunities, Advanced Engineering Informatics 25(4): 573-581. https://doi.org/10.1016/j.aei.2011.07.003

Welle, B.; Rogers, Z.; Fischer, M. 2012. BIM-centric daylight profiler for simulation (BDP4SIM): A methodology for automated product model decomposition and re-composition for climate-based daylighting simulation, Building and Environment 58: 114-134. https://doi.org/10.1016/j.buildenv.2012.06.021 
Wetzel, E. M.; Thabet, W. Y. 2015. The use of a BIM-based framework to support safe facility management processes, Automation in Construction 60: 12-24. https://doi.org/10.1016/j.autcon.2015.09.004

Won, J.; Lee, G. 2016. How to tell if a BIM project is successful: A goal-driven approach, Automation in Construction 69: 34-43. https://doi.org/10.1016/j.autcon.2016.05.022

Won, J.; Cheng, J. C. P.; Lee, G. 2016. Quantification of construction waste prevented by BIM-based design validation: Case studies in South Korea, Waste Management 49: 170-180. https://doi.org/10.1016/j.wasman.2015.12.026

Won, J.; Lee, G.; Dossick, C.; Messner, J. 2013. Where to focus for successful adoption of Building Information Modeling within organization, Journal of Construction Engineering and Management 139(11).

https://doi.org/10.1061/(ASCE)CO.1943-7862.0000731

Wong, J. K. W.; Zhou, J. 2015. Enhancing environmental sustainability over building life cycles through green BIM: A review, Automation in Construction 57: 156-165. https://doi.org/10.1016/j.autcon.2015.06.003

Wong, J. K.-W.; Kuan, K.-L. 2014. Implementing 'BEAM Plus' for BIM-based sustainability analysis, Automation in Construction 44: 163-175. https://doi.org/10.1016/j.autcon.2014.04.003

Wong, P. F.; Salleh, H.; Rahim, F. A. M. 2015. A relationship framework for Building Information Modeling (BIM) capability in quantity surveying practice and project performance, Informes De La Construccion 67: 119. https://doi.org/10.3989/ic.15.007
Wu, W.; Issa, R. R. A. 2014. BIM education and recruiting: Survey-based comparative analysis of issues, perceptions, and collaboration opportunities, Journal of Professional Issues in Engineering Education and Practice 140(2). https://doi.org/10.1061/(ASCE)EI.1943-5541.0000186

Wu, W.; Issa, R. R. A. 2015. BIM execution planning in green building projects: LEED as a use case, Journal of Management in Engineering 31(1): 1-18. https://doi.org/10.1061/(ASCE)ME.1943-5479.0000314

Xiong, X.; Adan, A.; Akinci, B.; Huber, D. 2013. Automatic creation of semantically rich $3 \mathrm{D}$ building models from laser scanner data, Automation in Construction 31: 325-337. https://doi.org/10.1016/j.autcon.2012.10.006

$\mathrm{Xu}, \mathrm{H}$.; Feng, J.; Li, S. 2014. Users-orientated evaluation of building information model in the Chinese construction industry, Automation in Construction 39: 32-46. https://doi.org/10.1016/j.autcon.2013.12.004

Yalcinkaya, M.; Singh, V. 2015. Patterns and trends in Building Information Modeling (BIM) research: A latent semantic analysis, Automation in Construction 59: 68-80. https://doi.org/10.1016/j.autcon.2015.07.012

Zhang, J.; Schmidt, K.; Li, H. 2016. BIM and sustainability education: Incorporating instructional needs into curriculum planning in CEM programs accredited by ACCE, Sustainability 8(6): 525. https://doi.org/10.3390/su8060525

Zhao, X. 2017. A scientometric review of global BIM research: Analysis and visualization, Automation in Construction 80: 37-47. https://doi.org/10.1016/j.autcon.2017.04.002

Timothy O. OLAWUMI. He is a full-time PhD research student under the supervision of Dr Daniel Chan at the Department of Building and Real Estate, Faculty of Construction and Environment, The Hong Kong Polytechnic University, Kowloon, Hong Kong. His research interest includes Building Information Modelling (BIM), Sustainability Studies, Construction Technology and Project management.

Daniel W. M. CHAN. Dr. He is an Associate Professor at the Department of Building and Real Estate and the Associate Head (Teaching), Faculty of Construction and Environment, The Hong Kong Polytechnic University, Kowloon, Hong Kong. His research interests include Construction Time Performance (CTP), Construction Procurement Systems, Relational and Collaborative Contracting, Project Partnering and Strategic Alliancing, Guaranteed Maximum Price (GMP) and Target Cost Contracting (TCC) Schemes, New Engineering Contract (NEC), Public Private Partnership (PPP), Construction Safety Management. Dr Daniel Chan is also a Member of the Association for Project Management (UK) (MAPM), Member of the Hong Kong Institute of Construction Managers (MHKICM), Member of the American Society of Civil Engineers (MASCE). He is also a Member of the Hong Kong Institute of Project Management (MHKIPM), Member of the Australian Institute of Project Management (MAIPM), Member of the Chartered Association of Building Engineers (MCABE), and Member of the Australian Institute of Building (MAIB).

Johnny K. W. WONG. Dr. He is an Associate Professor at the School of Built Environment, Faculty of Design, Architecture and Building, University of Technology Sydney, Sydney, Australia. His research interests include Green and intelligent building, Green BIM (Building Information Modelling), Age-friendly built environments, Culture in the construction industry. Dr Johnny Wong is a qualified member (MRICS) of the Royal Institution of Chartered Surveyors (UK). 